\title{
Phase II Final Project Report SBIR Project: “A High Efficiency PV to Hydrogen Energy System"
}

DOE Award Number: DE-FGO2-04ER83900

Recipient: Amonix, Inc.

Title: A High Efficiency PV to Hydrogen Energy System

DOE project director/officer: Alec Bulawka

Principal Investigators: A. Slade, J. Turner, K. Stone, R. McConnell

Teaming members: Arizona Public Service

\section{Executive Summary}

The innovative research conducted for this project contributed greatly to the understanding of generating low-cost hydrogen from solar energy. The project's research identified two highly leveraging and complementary pathways. The first pathway is to dramatically increase the efficiency of converting sunlight into electricity. Improving solar electric conversion efficiency directly increases hydrogen production. This project produced a world record efficiency for silicon solar cells and contributed to another world record efficiency for a solar concentrator module using multijunction solar cells. The project's literature review identified a second pathway in which wasted heat from the solar concentration process augments the electrolysis process generating hydrogen. One way to do this is to use a "heat mirror" that reflects the heat-producing infrared and transmits the visible spectrum to the solar cells; this also increases solar cell conversion efficiency. An economic analysis of this concept confirms that, if long-term concentrator photovoltaic (CPV) and solid-oxide electrolyzer cost goals can be achieved, hydrogen will be produced from solar energy cheaper than the cost of gasoline.

The potential public benefits from this project are significant. The project has identified a potential energy source for the nation's future electricity and transportation needs that is entirely "home grown" and carbon free. As CPV enter the nation's utility markets, the opportunity for this approach to be successful is greatly increased. Amonix strongly recommends further exploration of this project's findings.

\section{Project Goals and Objectives}


The project goal is to generate low-cost hydrogen on a large scale using a high efficiency concentrator photovoltaic (CPV) system. Previous solar-to-hydrogen economic analyses have shown that the high cost and low efficiency of conventional photovoltaic systems result in unacceptably high hydrogen costs using conventional electrolyzers. CPV systems have potential for low cost in large-scale production and have demonstrated the highest efficiency conversion of sunlight into electricity.

Task objectives were to 1) demonstrate hydrogen production on a large-scale, 2) develop an interface to match temperature and voltage between the solar concentrator and the electrolyzer, and 3) fabricate solar cells capable of operating at very high efficiency under highly concentrated sunlight.

Based on what was accomplished and discovered during this project this report provides recommendations for future development of CPV systems generating lowcost hydrogen.

\section{Project Accomplishments}

Soon after this contract's award, work stopped on Task 1 when Amonix's partner, Arizona Public Service gave notice that a surplus electrolyzer identified for this task was not longer available. Amonix informed the DOE project director and noted that Task 1 was a relatively small part of the project's planned budget.

Work on Task 2 explored an innovative approach for creating a dynamic interface to match the voltage output of the CPV system to the electrolyzer's input. Initial discussions with a DC-to-DC converter supplier led to a dynamic control approach employing a peak hydrogen-production tracking system. The design was supposed to change the electrolyzer temperature so as to minimize losses arising from differences between the CPV output voltage and the electrolyzer input voltage. During supplier negotiations, the converter supplier decided they couldn't meet the project specifications, especially for a single unit. Therefore work on this task stopped except for additional literature studies. The literature review, late in the project's final phases, identified a dramatically different approach using a spectral splitter ("heat mirror") to separate infrared solar energy from the visible in CPV systems. Australian researchers had demonstrated that fiber optics could conduct the infrared energy to heat a high-temperature, solid-oxide electrolyzer, thereby dramatically increasing the efficiency of hydrogen production. This approach utilizes heat from solar concentration to boost hydrogen production instead of dissipating it to the environment. System analyses predict a reduction in the cost of hydrogen by a factor of 3 and more for this concept when compared with hydrogen production costs from conventional flat-panel PV systems. While there was no opportunity to pursue this approach during this SBIR project, it is a promising approach suitable for additional exploratory research and development.

Amonix reported the problems in executing Task 1 and Task 2 to the DOE project officer and proposed that Amonix focus only on Task 3. Task 3's objective is to fabricate the highest efficiency solar cells for use in concentrated sunlight thereby 
generating the maximum amount of electricity for water electrolysis. Since Task 3 already had the largest funding allocation for the project, the SBIR technical monitor concurred with this departure from the original set of Tasks. Specifically, Task 3 supported the development of the world's highest efficiency solar cells using both conventional crystalline silicon and materials from columns 3 and 5 of the periodic table, so-called III-V solar cells. This task led to the project's primary accomplishments of new world records for solar concentrator solar cells and modules.

Project subtask 3a targeted the manufacture and packaging of advanced silicon solar cells for very high concentration. We designed new photomasks for fabricating contacts and used them for processing a new solar cell design. An alternative design employed a higher number of reduced area contact pads; however yields were too low to proceed with that design. The successful design had a standard three-pad configuration with additional design improvements.

Subtask $3 \mathrm{~b}$ supported the procurement of multijunction solar cells having $37 \%$ efficiencies, approximately 10 percentage points higher than the efficiencies of the best silicon solar cells. We mounted these cells in solar concentrator packages and successfully tested them in operation.

Subtask 3c focused on a new optical design for concentrating sunlight by a factor of 1000 thereby reducing the number (and cost) of expensive solar cells. An additional success of this task was the development of a new secondary optical element (SOE) that doubled the concentration ratio from $500 x$ to $1000 x$ while actually increasing the tracking tolerance for pointing the solar concentrator at the sun.

Subtask $3 \mathrm{~d}$ united the results of the other subtasks in world-record demonstrations for converting solar energy into electricity. First, Amonix achieved a world record efficiency of $27.6 \%$ (See Figure 1 below) for silicon concentrator solar cells (1). Integrating these cell improvements into Amonix's MegaModule contributed to an increase in its efficiency. A complete MegaModule, approximately 11 feet $(3.4 \mathrm{~m})$ on a side and 45 feet (13.7) long, contains over 1000 solar cells. One MegaModule was outfitted with the new silicon solar cells and SOEs. The retrofitted MegaModule demonstrated an improvement of more than one percentage point in efficiency. Each percentage point increase represents a ten-watt increase per square meter of available sunlight under ideal weather conditions. In the case of the Amonix MegaModule, it produced 180 watts (DC power before accounting for system efficiencies) for each square meter compared with 170 watts for the previous version. As significant as this result was we demonstrated an even more dramatic increase with multijunction solar cells. Because of the limited availability of these new $37 \%$ efficient solar cells, we prepared a $1 \mathrm{~m}^{2}$ submodule (receiver plate and lenses) with 30 solar cells that tested over 28\% DC efficiency in 2006 (2). The combined efficiency of $28 \%$ for a full receiver plate of multijunction cells outstripped all of the remaining planned improvements for Task 3. 


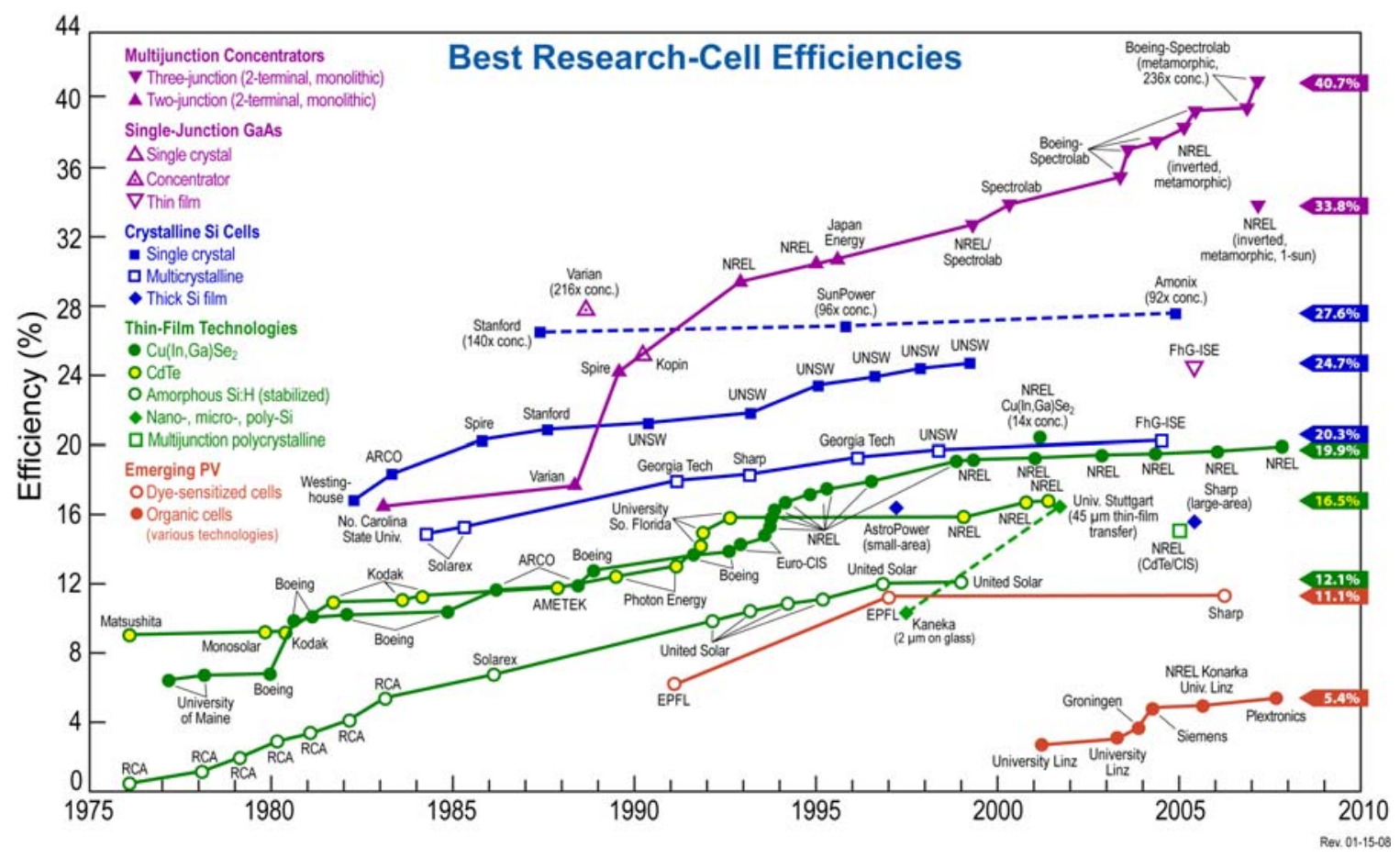

Figure 1 NREL's summary of champion cell efficiencies for various photovoltaic technologies (1). Note Amonix record efficiency of $27.6 \%$ at end of dashed line.

The significance of this last result is worth further discussion. As summarized in Figure 1, researchers have reported record efficiency cells for a variety of solar cell technologies. However, these cells were, by definition, carefully selected as the best ones found among many. They were tested under laboratory conditions using solar simulators with forced cooling of the cells. A full receiver plate of production cells operating outdoors at ambient temperatures and registering more than $28 \%$ submodule efficiency is a record on its own. When cells are operated together, there is always a combination of losses due to variations in their individual currentvoltage (IV) characteristics, external resistance of electrical interconnects, heat conduction out of the cells, mechanical variations in concentrating optics and overall alignment of each cell with its lens. The net result of a receiver plate of 30 cells is the capability of $28 \%$ solar conversion efficiency in real world conditions, compared with $10 \%$ to $17 \%$ for conventional flat-plate solar modules. This is a significant improvement over conventional photovoltaic solar efficiencies.

\section{Hydrogen Generation Cost Comparison}

We are now in a position to understand why this new high-efficiency solar electric technology invites a fresh look at the challenge of generating hydrogen from water using sunlight. The generation of electrolytic hydrogen from solar energy is critically important to the world's long-term energy needs for several reasons. The feedstock (water) and supplied energy (solar) are inherently carbon free so that on a life-cycle basis, the total carbon emissions will be significantly less than those from fossil-based options for generating hydrogen. And there is the potential to generate 
hydrogen near its markets, thus minimizing transportation costs. In the past, the principal criticism of photovoltaics for generating hydrogen has been the high cost of PV electricity and the inefficiencies of the conversion processes, particularly the PV process for converting sunlight into electricity.

As we have seen, CPV systems have the potential for generating lower-cost electricity, primarily due to the commercial availability of high-efficiency multijunction III-V solar cells with efficiencies above $35 \%$. But solar concentrator systems can also contribute heat to improve and enhance the electrolysis efficiency of water in a high-temperature solid-oxide electrolyzer. This heat boost $-40 \%$ as reported for electrolyzer temperatures above $1000^{\circ} \mathrm{C}$ in the $1990 \mathrm{~s}$ patents of the Australian company Solar Systems [3,4]-has been substantiated in recent theoretical analyses [5]. This new pathway provides significant engineering and economic benefits for generating electrolytic hydrogen from solar energy, thereby creating opportunities for PV to contribute to future transportation markets using low-cost hydrogen.

The pathway described in the Australian patents is shown in Figure 2 below.

\section{Hybrid Solar Concentrator PV System for the Electrolytic Production of Hydrogen}

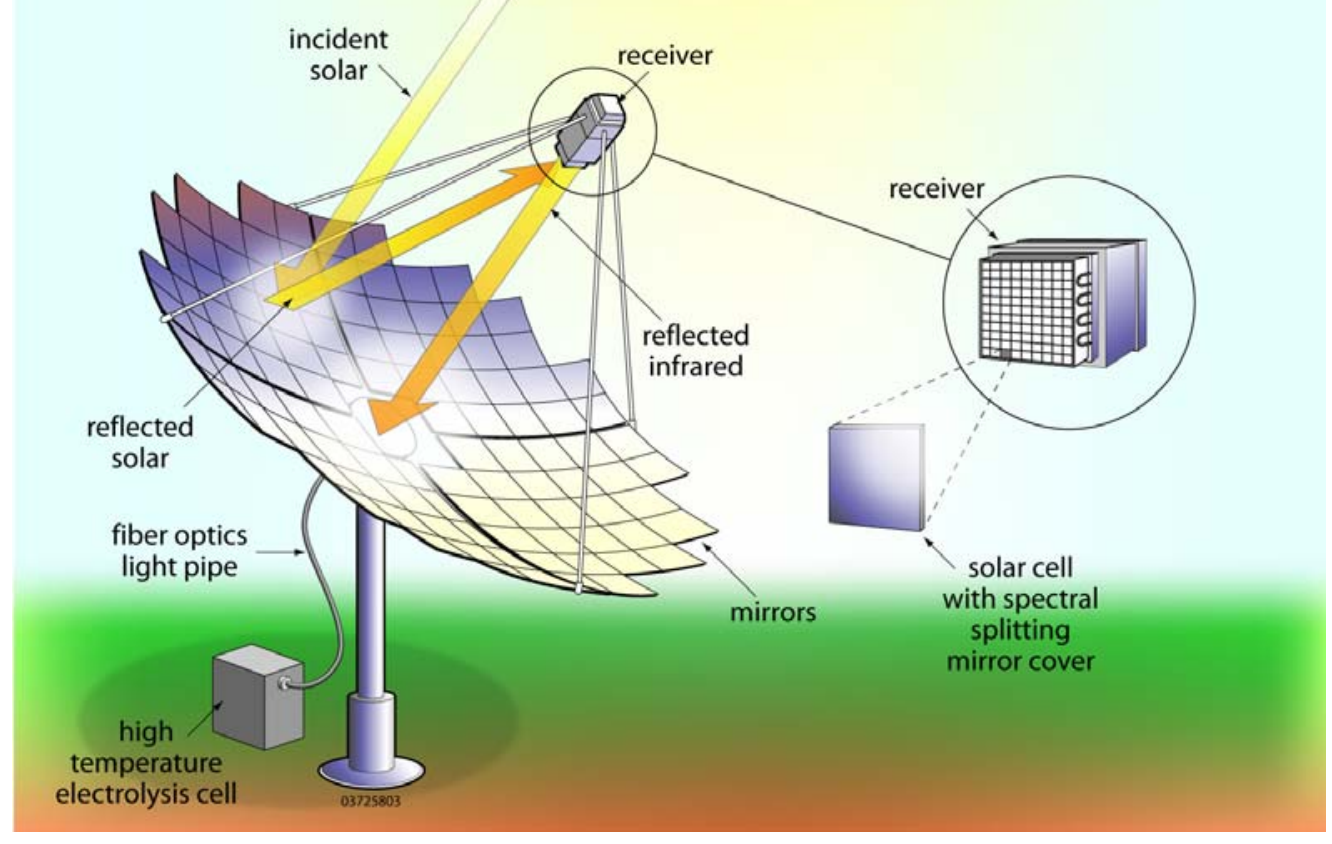

Figure 2. Schematic of system shows sunlight reflected and focused on the receiver, with reflected infrared directed to a fiber-optics light pipe for transport to a high-temperature solid-oxide electrolysis cell. Solar electricity is sent to the same electrolysis cell, which is able to use both heat and electricity to split water. 
The reflected infrared radiation is gathered by a fiber optics "light pipe" and conducted to the high-temperature solid-oxide electrolysis cell. The electrical output of the solar cells also powers the electrolysis cells. About 120 megajoules are needed-whether in electrical or thermal form, or both-to electrolyze water and generate $1 \mathrm{~kg}$ of hydrogen. The result is that more of the solar energy is used for hydrogen production. And we shall see that the additional costs for the hybrid solar concentrator components-the spectral splitter and optical fibers-are relatively small compared with the overall increase in hydrogen production. Finally the Australian patents were based on CPV systems using mirrors. To use this concept for a CPV system with lenses, a different spectral splitter geometry and light pipe design would be needed to collect the infrared radiation from all of the solar cells. There have been numerous studies of spectral splitting concepts for photovoltaic technologies (6). We hope to explore some different possibilities for the Amonix refractive $\mathrm{CPV}$ system in future work.

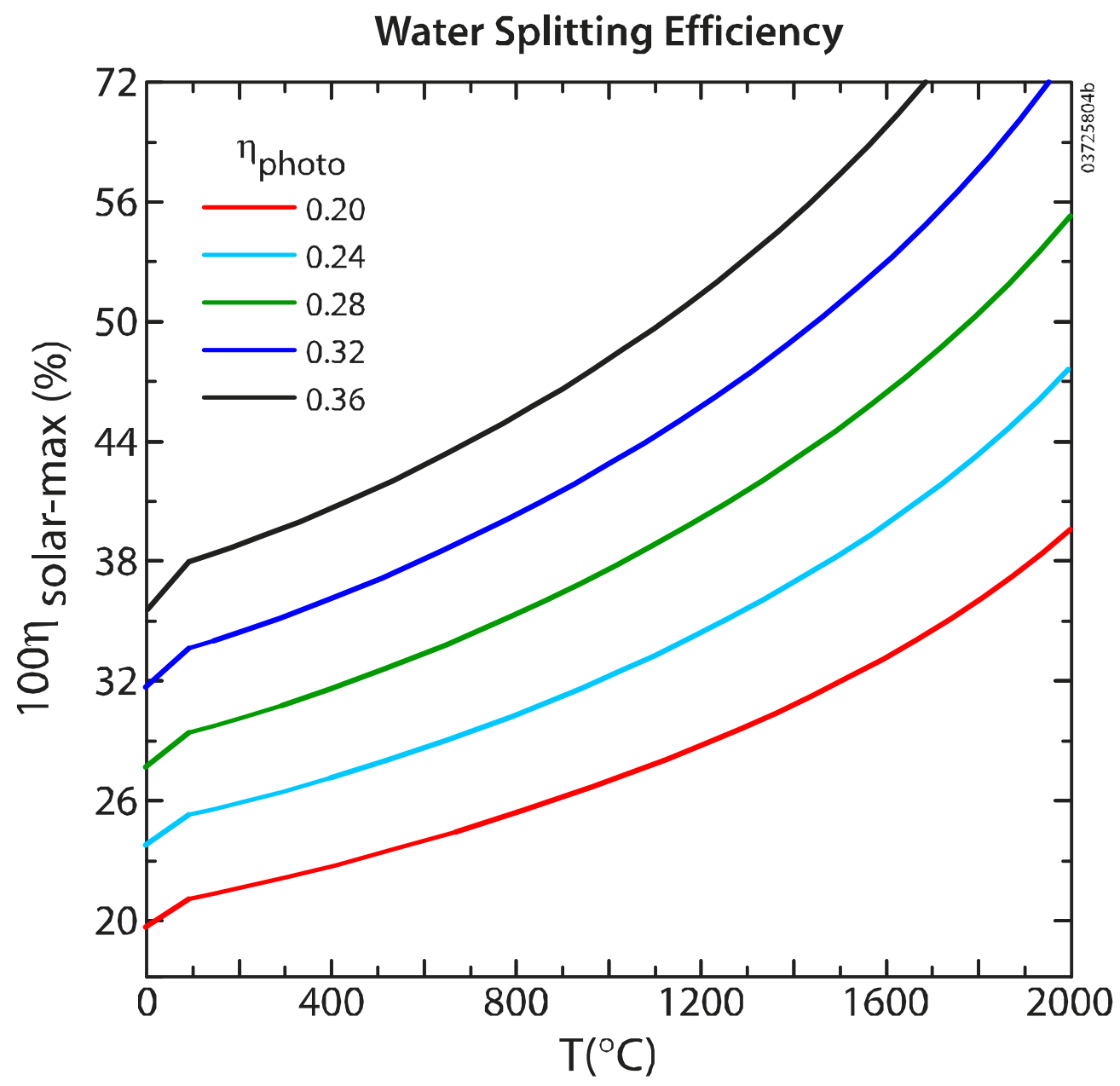

Figure 2. Energy conversion efficiency of solar-driven water splitting to generate $\mathrm{H}_{2}$ as a function of temperature and photovoltaic conversion efficiency at AM1.5 insolation, at $\mathrm{pH}_{2} \mathrm{O}=1$ bar [5]. 
Assuming a heat boost of $40 \%$, a multijunction solar cell efficiency of $35 \%$, and an optical efficiency of $85 \%$ the system would have $40 \%$ efficiency for the conversion of solar energy to hydrogen for electrolyzer temperatures of $1000^{\circ}$ C. A $40 \%$ multijunction solar cell would yield a solar-to-hydrogen conversion efficiency of almost $50 \%$ even for electrolyzer temperatures as low as $800^{\circ} \mathrm{C}$. Electrochemical theoretical results calculated by Licht and shown in Figure 3 are consistent with these projections [5].

The largest cost for the hybrid solar concentrator system will be for the dish concentrator and PV receiver, shown in Figure 2. Algora completed an extensive cost analysis based on previously collected data for CPV systems and extrapolated to very mature CPV systems [7]. Many of the project costs came from installed costs for the 480-kW reflective CPV system in Tenerife, Spain. The analysis included a wide range of parameters, including cumulative production of $10 \mathrm{MW}$ for present-day systems to cumulative production of $1000 \mathrm{MW}$ for the mid-term systems where "learning" cost reductions are incorporated. Concentrations ranged from 400 to 1000 suns, with solar cell efficiencies ranging from 32\% to 40\%. Module efficiencies ranged from $24.8 \%$ to $32.2 \%$, and the plant's AC annual efficiency ranged conservatively from $18.2 \%$ to $23.6 \%$. Algora's analysis projected long-term electricity costs of $\$ 0.05 / \mathrm{kWh}$ (comparable with electricity costs from today's wind systems) for efficiencies of 40\%, 1000-suns concentration, good solar resource and multi-gigawatt production. In our estimation, these are long-term projections requiring significant research, development and manufacturing achievements that are not impossible for CPV systems.

Using these projected costs, McConnell, Lasich and Elam (8) estimated the cost of hydrogen generated by a very mature version of this hybrid solar concentrator concept. They compared the results with the cost of hydrogen generated from mature wind energy systems as well as from the conventional reformation of natural gas.

Table 1 summarizes the cost data for a mature technology (gigwatts of cumulative production) for the hybrid CPV system and high-temperature solid-oxide electrolysis cell. A fuel cell/electrolyzer company projected costs for a mature solidoxide electrolysis technology. Table 2 summarizes the hydrogen production costs for a 10-MW CPV project built assuming these mature components. It assumes a $20 \%$ rate of return per year and did not include operating, storage, or delivery costs. Table 3 compares these production costs with those of other hydrogen production technologies. While the uncertainties are much larger for hybrid solar concentrator costs the results fall close enough to those of mature technologies for generating hydrogen that further study is warranted. Further, hydrogen costs using conventional photovoltaic technologies are almost 3 times larger (8). 
Component Costs for $10 \mathrm{MW}$ hybrid CPV system

$(\$ / \mathrm{kW})$

Concentrator PV

800

Spectral splitter

15

Fiber optics

25

Electrolysis cell

400

Total System Cost

1240

Table 1: Component and system costs for a $10 \mathrm{MW}$ hybrid CPV project for solid-oxide electrolytic production of hydrogen. The CPV cost is based on a mature technology with a production capacity of many $1000 \mathrm{MW} /$ year.

Hydrogen Cost Data for Mature Technology

Plant size (MW) 10

Plant cost (\$ million) $\quad 12.4$

$\mathrm{H}_{2}$ produced $(\mathrm{kg} / \mathrm{yr}) \quad 10^{6}$

Hydrogen cost $(\$ / \mathrm{kg}) \quad 2.48$

Table 2: Hydrogen production data for mature 10-MW plant. The estimated hydrogen cost of $\$ 2.48 / \mathrm{kg}$ has considerable uncertainty related to long-term projections for a relatively immature technology.

Process HydrogenProductionCost

$(\$ / \mathrm{kg})$

Gas reformation

Wind electrolysis

Hybrid CPV electrolysis (this estimate) 2.48

Table 3: Cost comparison for the hybrid CPV production of electrolytic hydrogen. Note that $1 \mathrm{~kg}$ of hydrogen has the energy equivalent of one U.S. gallon of gasoline (8). 
The literature contains many cost analyses for hydrogen production, but the assumptions behind the analyses vary dramatically. The DOE, through its Hydrogen Program, is establishing a cost-analysis structure for comparing different hydrogen and fuel cell technologies within a common set of assumptions. The hybrid CPV result in Table 3 is a preliminary estimate needing additional work for a careful comparison with results for these very mature technologies. CPV systems are just beginning to enter the energy market so cost uncertainties are significant compared with those of highly developed wind systems with a worldwide installed capacity approaching $100 \mathrm{GW}$. Nevertheless, these preliminary hydrogen costs, less than the energy-equivalent cost of gasoline today, are comparable with hydrogen costs from wind electrolysis. Additional cost studies are warranted. Today, wind system costs are in the $\$ 1000 / \mathrm{kW}$ range-as are the estimated costs for future highly developed CPV systems (7)-whereas wind electrolysis can't provide a heating boost in electrolysis efficiency. Assuming these cost analyses continue to be positive, this hybrid CPV technology is worthy of further exploration and development.

The uncertainties in this cost analysis arise principally from the early stage of technology development for solar concentrators, high-efficiency solar cells, and solid-oxide electrolysis cells. There are many positive indications that these technologies can achieve their performance and cost potentials, but additional development will be needed.

\section{Summary of Project Activities}

This SBIR project's original hypothesis was that multiple innovations are needed to generate low-cost hydrogen from solar energy. We explored the use of the latest high efficiency solar cells to get dramatically more electricity for hydrogen generation; we created record-breaking demonstrations for converting sunlight to electricity under real-world conditions. We studied various approaches for optimizing the match between thermal and electrical outputs of the solar concentrator system and inputs to the electrolyzer system. We identified an approach using solar concentrator heat to increase the efficiency of hydrogen production. Considering the problems encountered in implementing the plan's original tasks, the project's outcomes are exemplary. We identified two dramatic and complementary pathways for generating low-cost hydrogen from solar energy. The two pathways are 1) demonstrating that dramatically higher solar electric conversion efficiencies can be achieved on a large-scale and 2) identifying a pathway for utilizing solar concentrator heat, normally considered a waste, for augmenting hydrogen production. It is not unusual in innovative research projects to encounter significant departures from research plans that lead to more significant results than expected originally. That is the situation for this project where losing the original electrolyzer led to consideration of another type of electrolyzer that can use the waste heat from solar concentrators. Losing the DC-toDC converter supplier led to a careful look of energy output from the solar concentrator (thermal plus electrical) and electrolyzer input (thermal plus electrical) that uncovered an opportunity to use a solar waste product, heat, to 
augment hydrogen production. Our preliminary cost studies confirm this technology has the potential to generate hydrogen at a cost competitive with gasoline costs. The successful development of this technology could therefore provide significant benefits for the nation's future energy needs.

\section{References}

1 S. Kurtz, "Opportunities and Challenges for Development of a Mature Concentrating Photovoltaic Power Industry," NREL/TP-520-43208, July 2008

2 V. Garboushian, R. Gordon, and A. Slade, "Why Concentrators?" Proceedings of Solar Power 2007, Long Beach, California, September 2007.

3 J. Lasich, U.S. Patent No. 5658448, August 19, 1997.

4 J. Lasich, U.S. Patent No. 5973825, October 26, 1999.

5 S. Licht, J. Phys. Chem. B107, 4253-4260, 2003.

6 A.G. Imenes and D.R. Mills, "Spectral Beam Splitting Technology for Increased Conversion Efficiency in Solar Concentrating Systems: A Review," Solar energy Materials \& Solar Cells 84, pp. 19-69, 2004.

7 C. Algora, Chapter 6 in Next Generation Photovoltaics, edited by A. Marti and A. Luque, Institute of Physics Publishing, Bristol and Philadelphia, 2004.

8 R.D. McConnell, J.B. Lasich, and C. Elam, "A Hybrid Solar Concentrator PV System for the Electrolytic Production of Hydrogen," Proceedings of the $20^{\text {th }}$ European Photovoltaic Solar Energy Conference and Exhibition, Barcelona, Spain, June 2005

\section{Appendix--Major Publications}

Amonix gratefully acknowledges the DOE SBIR funding that supported, either completely or partially, the publications in this appendix.

"A Comparison of Concentrator Cell Technologies" A. Slade, R. Gordon and V. Garboushian, Proc. 4th International Conf. on Solar Concentrators, Spain 2007

"Analysis of five years of field performance of the Amonix high concentration PV system", Kenneth W. Stone, Vahan Garboushian, Robert Boehm, Rick Hurt, Allison Gray, Herb Hayden, Powergen 2006, April, 2006, Las Vegas, NV

"27.6\% Efficient Silicon Concentrator Solar Cells for Mass Production", Alexander Slade and Vahan Garboushian, PVSEC 15 October 2005, Shanghai, China

Submitted to http://www.osti.gov/elink/241-3.jsp 


\title{
A COMPARISON OF CONCENTRATOR CELL TECHNOLOGIES
}

\author{
by \\ Alexander Slade, Robert Gordon and Vahan Garboushian \\ Amonix Inc. \\ 3425 Fujita Street \\ Torrance CA USA 90505
}

\begin{abstract}
An objective comparison between different concentrator cell types is performed in order to show the usefulness and drawbacks of available cell technologies. The analysis includes only high concentration photovoltaics and primarily discusses the Spectrolab multi-junctiontype cell and the Amonix silicon cell. It is found there are tangible benefits of the multi-junction for systems that have a high overall cost to produce. Interestingly, as the system cost falls below $\$ 2.00 /$ Watt it is the silicon cell that has a cost advantage. This results tells us that the multi-junction cells will be widely utilized as a starting point for the CPV industry but once volumes are in the GW range it could be that silicon concentrator cells will became the dominate lowest-cost technology. A cost model to support this analysis is presented for industry comment.
\end{abstract}

\section{INTRODUCTION}

Concentrator photovoltaics (CPV) aims to produce electricity from sunlight at a lower cost than conventional approaches to PV. The fundamental concept behind CPV is to use a solar cell that is much smaller than the optical collection area. The relatively small area of the solar cell potentially reduces the cost component of the cell and thereby reduces the overall cost of the system. A cost model is defined and used to assess the benefits of differing approaches to obtaining low-cost systems in flat-plate PV and is then applied to CPV systems. Two examples are chosen for the CPV model, a low-cost 25 $\%$ solar cell and a higher cost $35 \%$ cell. Using such a model it has been found that there is a cross over point that for relatively high system cost a high performance cell is required to reduce the overall system $\$ /$ Watt quotient. This has been widely published already, especially by manufacturers of multi-junction concentrator cells. However, a lesser known fact is that as the system cost reduces the cost advantage of a multi-junction concentrator cell also reduces until there is a point at which a low-cost $25 \%$ cell will produce a system cost with a lower \$/Watt cost.

The basis of comparing the low-cost $25 \%$ cell is to represent a silicon back-contact cell that Amonix has already produced and field tested for many years and has proven reliability and high $\mathrm{kWh} / \mathrm{kW}$ performance.

\section{A GENERALIZED COST MODEL}

For any particular PV system, there are a number of components incorporating solar cells and modules, structural and control electronics parts, installation (labor) costs and grid interconnection electronics and manufacturing labor (cost of sales, engineering, etc). Calculating the overall system cost is done assuming a model of system cost without the module and then adding either a high-efficiency, high-cost module or a low-efficiency, low-cost module; the results of the calculation for a system of fixed physical size (such as $2001 \mathrm{~m}^{2}$ modules) are plotted in figure 1. The high cost, high performance modules are $12 \%$ multicrystalline silicon that cost either $\$ 4 / \mathrm{W}$ or $\$ 3 / \mathrm{W}$ and the low performance, low cost modules are $6 \%$ efficient thin film-type panels costing $\$ 2 / \mathrm{W}$ or $\$ 1 / \mathrm{W}$. It can be seen that for high system (without the module) costs, the more efficient panels produce a lower system cost. As the cost of the system without the module reduces, there is a cross over point where the thin film-type modules reduce the finished system cost. This model can be thought to represent a residential installation in the high cost region and a 10+ MW installation for the low cost region. This model is well supported by actual installations as we see residential systems are preferentially made with higher output modules and large installations are increasingly favoring low-cost thin film modules in order to reduce the overall system cost. As there are many regions in the world that have large differences in the amount of sun light throughout the year and the cost of labor, land, etc can differ greatly, this simple model shows that for a given location, there is generally a best fit technology. Other aspects to a flat-plate installation such as system design costs, tracking, and, the particular modules' response to varying sunlight conditions, can make a calculation of the general levelized cost of electricity (LCOE) very difficult to determine. However, the general result here is that the PV technology should match the system expense.

Taking this same model to CPV we see that there is also a variation in PV cell technology. The silicon backcontact concentrator cell has shown efficiencies over $25 \%$ and it is practically limited to less than $30 \%$. However, due to the large silicon semiconductor industry, there is ample silicon material and manufacturing capacity/expertise to produce 500x

"A COMPARISON OF CONCENTRATOR CELL TECHNOLOGIES", A. Slade, R. Gordon and V. Garboushian, Proc. $4^{\text {th }}$ International Conf. on Solar Concentrators, Spain 2007. 
concentrator cells in very high volumes and at low cost. The alternative to the silicon concentrator cell is the multijunction solar cell that has shown efficiencies just over $40 \%$. However, the cost of the multijunction cells is significantly higher than silicon - the raw Ge wafers used to produce the multijunction cells are 8 times more expensive that prime grade silicon wafers, as one example. So, in recognition of the two very different technologies, Amonix was particularly interested in assessing the best direction for system development do we aim to use these $40 \%$ multijunction or continue with our own silicon technology? The above cost models used again to assess the best-fit technology for a CPV system but with the multicrystalline and thin film $\mathrm{PV}$ modules replaced with silicon and multijunction cells. This direct replacement of the cells is, in the first order, valid, due to the use of the same system design and materials for both cell technologies. However, the multijunction cell has aspects to it that require manufacturing equipment and processes that are more sophisticated than is needed for silicon cells. For the purpose of simplicity, we consider these more demanding aspects of using the multijunction cells to be second order considerations and are therefore not considered for this analysis.

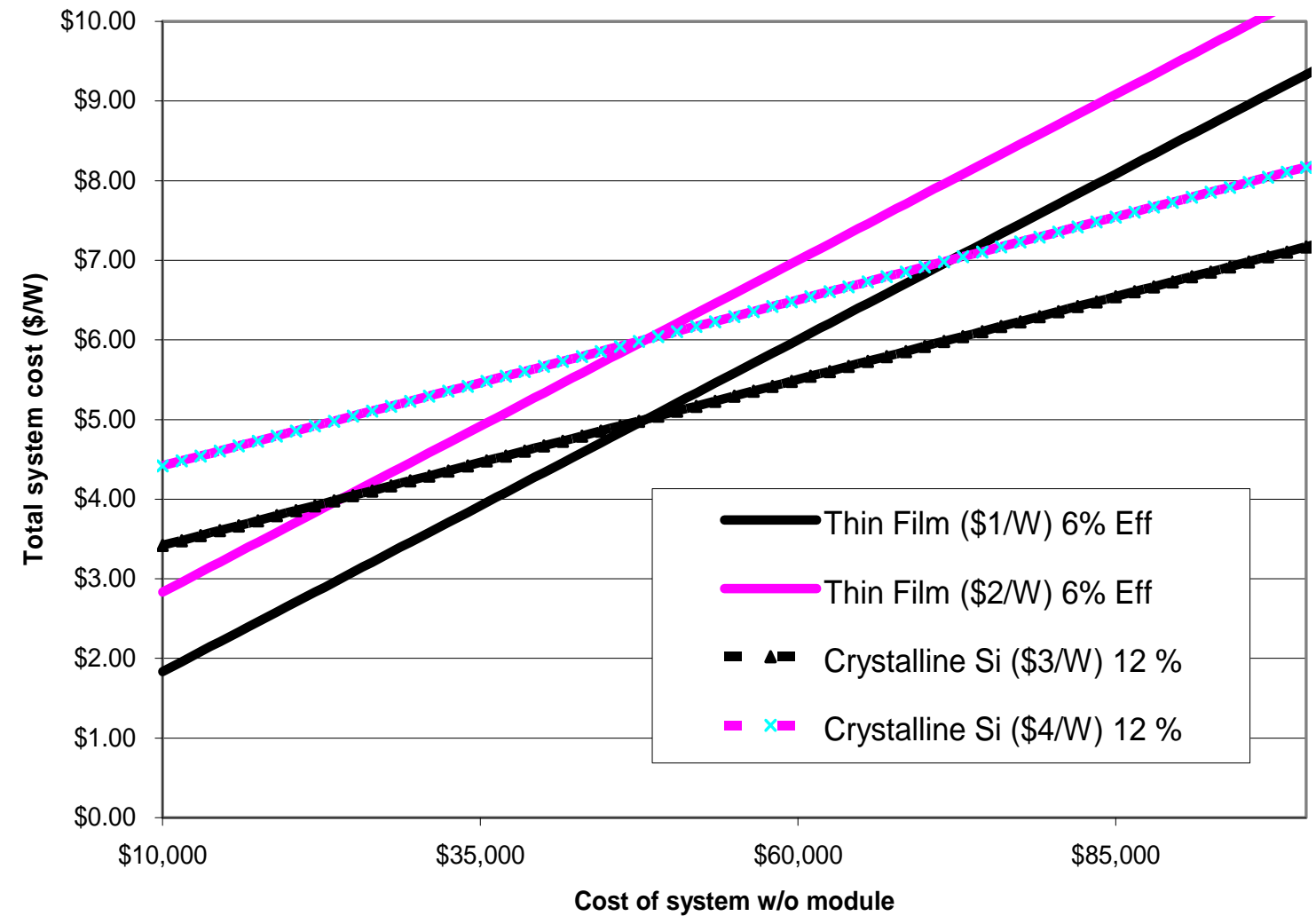

Figure 1. Calculation of system cost is presented as a function of module cost and efficiency and is plotted against the cost of the installation including all components and labor minus the PV module.

From the aforementioned conditions we have produced the same calculation for CPV system as we did for 1sun system and plotted the data in figure 2. The data in figure 2 shows that the higher efficiency, higher cost cell reduces the system cost for more expensive installations. Once the cost of the system (without the cell) decreases, the advantage of the multijunction cell begins to diminish. Furthermore, there is also a cross over point for CPV systems where the final system cost is lower when a silicon cell is used, as was seen for the 1-sun system analysis. For near-term cell costs and efficiency levels, the cross over point is near $\$ 3 / \mathrm{W}$, thereafter the overall system cost is less expensive if a silicon cell is used in place of a multijunction cell. The second group of lines show that the cross over point is reduced to $\$ 2.50 / \mathrm{W}$ if both of the cell costs are reduced to the level we expect for 50 - $100 \mathrm{MW}$ production.

"A COMPARISON OF CONCENTRATOR CELL TECHNOLOGIES", A. Slade, R. Gordon and V. Garboushian, Proc. $4^{\text {th }}$ International Conf. on Solar Concentrators, Spain 2007. 


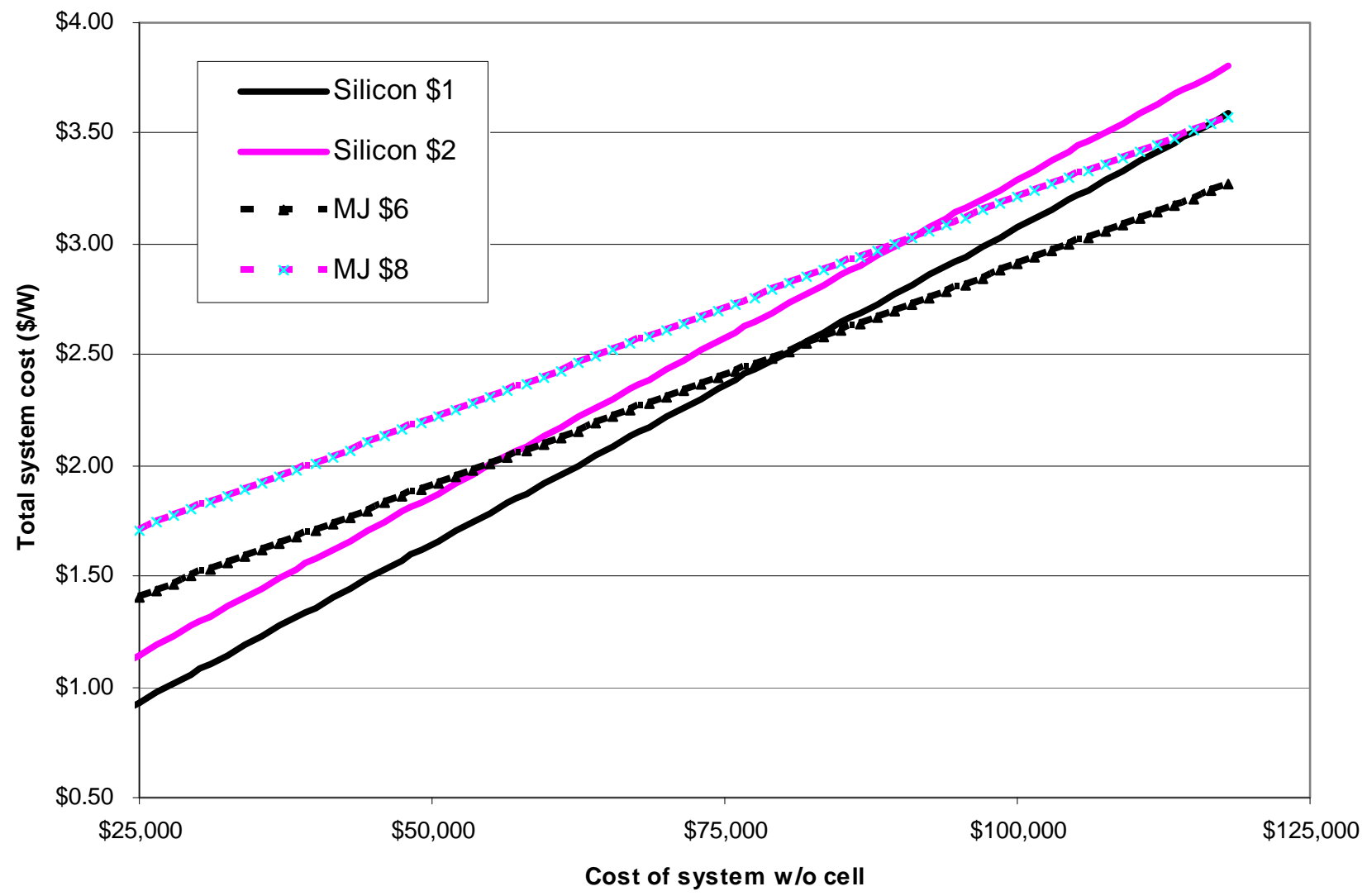

Figure 2. Calculation of system cost is presented as a function of concentrator cell cost and efficiency and is plotted against the cost of the installation including all components and labor minus the cells.

\section{DISCUSSION}

It has been stated many times by many burgeoning CPV companies that their mission is to reduce the cost of $P V$ systems, relative to the established flat-plate technology. We have seen from the system-level analysis presented here that the future of low cost systems requires a low cost cell. This is somewhat in contradiction to the current enthusiasm to use a multijunction cell in CPV as it is currently relatively expensive. However, we can see that the multijunction cell offers cost benefits to the system when the cost is in excess of $\$ 2.50-\$ 3.00 / W$. This hasn't happened yet even for the established 1-sun PV industry. This being the case we could argue that the multijunction cells' main advantage is for short term system manufacturing and installation. Unfortunately, there is a drawback to this as there has been $10+$ years of device and process development, field testing and packaging experience with the silicon cell but little more than 1 year experience with the multijunction cell. This lack of device history makes adopting the new technology difficult, especially as the device development appears to be on-going, so what is field tested now may not be relevant in 1-2 years time when the device development of the multijunction stabilizes. However, as there are only two companies that have produced a low cost silicon concentrator cell, access to the silicon technology is difficult. Amonix produces the cell only for their own system and SunPower no longer manufactures concentrator cells.

One more noteworthy caveat is that the multijunction cells may well become significantly more competitive if the costs can be reduced or once the efficiency reaches $50 \%$ for high volume production cells, especially as the silicon cells' efficiency will always remain below $30 \%$.

\section{CONCLUSION}

To produce the lowest overall cost for a PV system requires:

- Low component costs, and

- Inexpensive solar cells

However, there is motivation to use a relatively expensive, high performance solar cell technology if the system cost remains high. As an example of this, a residential PV system would benefit from using high

"A COMPARISON OF CONCENTRATOR CELL TECHNOLOGIES", A. Slade, R. Gordon and V. Garboushian, Proc. $4^{\text {th }}$ International Conf. on Solar Concentrators, Spain 2007. 
efficiency modules whereas a very large installation in desert areas would be better designed to make use of a thin-film module. The same is true for concentrator systems that a multijunction cell will reduce the cost of an expensive system but a silicon cell is better for a CPV system if the system cost is low.

"A COMPARISON OF CONCENTRATOR CELL TECHNOLOGIES", A. Slade, R. Gordon and V. Garboushian, Proc. $4^{\text {th }}$ International Conf. on Solar Concentrators, Spain 2007. 


\title{
ANALYSIS OF FIVE YEARS OF FIELD PERFORMANCE OF THE AMONIX HIGH CONCENTRATION PV SYSTEM
}

\author{
Kenneth W. Stone \\ Vahan Garboushian \\ Amonix, Inc. \\ 3425 Fujita St. \\ Torrance, California 90505 \\ Ph: 310-325-8091 \\ Fax: 310-325-0771 \\ kennethwstone@yahoo.com
}

\author{
Robert Boehm \\ Rick Hurt \\ Allison Gray \\ University of Nevada, Las Vegas \\ Box 454027 \\ Las Vegas, NV 89154-4027 \\ Ph: 702-895-0429 \\ boehm@me.unlv.edu
}

\author{
Herb Hayden \\ Arizona Public Service \\ 400 North $5^{\text {th }}$ \\ Phoenix, Arizona 85072 \\ Ph: 602-316-0207 \\ Fax: 602-250-3813 \\ hhayden@apsc.com
}

\begin{abstract}
This paper analyzes the power, energy, and reliability performance of the Amonix High Concentration Photovoltaic (HCPV) technology. Field performance data have been gathered from five different sites over the last five years for the $570 \mathrm{~kW}$ of installed systems that have generated over $3 \mathrm{GWh}$ of grid power during this time. A description is given of each site including the plant size, operating time, and amount of energy generated. The data is analyzed from different aspects to determine the long-term performance of the system. This includes the total accumulated energy generated at the different sites since the start of the development program. Reliability and O\&M data are presented from one of the units located at the Center for Energy Research on the campus of the University of Nevada, Las Vegas.
\end{abstract}

\section{INTRODUCTION}

Amonix was formed in the 1990s to commercialize a high concentration silicon solar cell developed at Stanford University. Several configurations of structure, drives, and controls were manufactured and field-tested before arriving at the commercial configuration shown in Figure 1 in early 2000. To verify the manufacturability of the system and develop manufacturing procedures and processes, a commercial manufacturing center was established. To verify the field performance, units were installed at various sites and operated to determine short term and long term operating

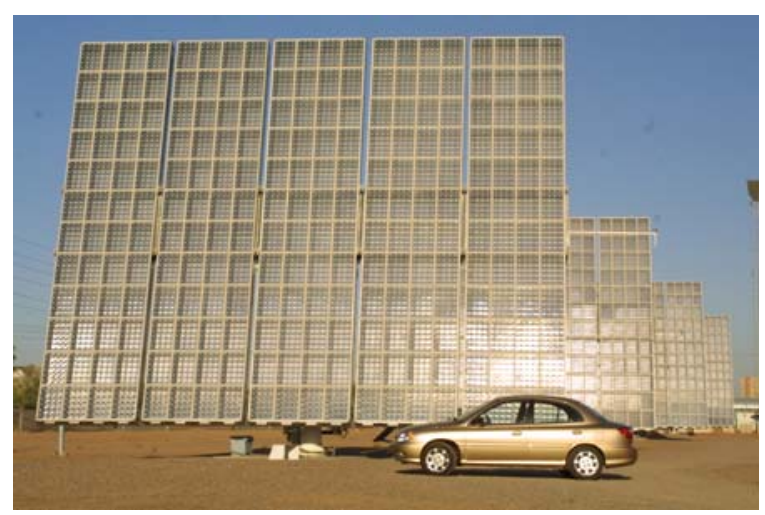

Figure 1. Amonix 25 kW HCPV system. problems. Over $570 \mathrm{~kW}$ of the systems were manufactured, installed, and tested at various locations to verify the performance of the design. Units have been installed for Arizona Public Service (APS), University of Nevada Las Vegas (UNLV), Nevada Power Company, Southern California Edison (at California State Polytechnic University, Pomona, CA), and Southwest Solar Park in Texas. Some of these units have now been in operation for nearly six years.

\section{WHY CONCENTRATION}

Before photovoltaic systems can provide a substantial part of the world's need for electrical energy, there needs to be a large reduction in the cost. Studies conducted by Department of Energy (DOE) (Ref-1), Electrical Power Research Institute (EPRI) (Ref-2), and others (Ref-3) 
show that concentrating solar energy systems can eventually achieve lower costs than conventional PV power systems. The lower cost results from:

1. Less expensive material - Because the semiconductor material for solar cells is a major cost element of all photovoltaic systems, one approach to cost reduction is to reduce the required cell area by concentrating a relatively large area of solar insolation onto a relatively small solar cell. Amonix has pursued this approach to lower system cost. Amonix is using low-cost Fresnel lenses to focus the sun power onto the cells, which reduces the required cell area/material by nearly 250 times. A 6” wafer used in a flat plate PV system will produce about 2.5 watts but will produce 1000 watts in the Amonix system as illustrated in Figure 2.

2. Higher efficiency - Concentrating PV cells achieve higher efficiencies than do nonconcentration PV cells. Flat plate silicon cells have efficiencies in the range of $8 \%$ to $15 \%$ while the Amonix concentrating silicon cell has an efficiency of $26 \%$. Concentrating multijunction cells are still in the development stage but have achieved efficiency greater than $34 \%$.

3. More annual energy - Increased annual energy production is achieved by the incorporation of two-axis sun tracking. All high-concentration systems require a suntracking control system. This results in additional annual energy generation per installed kW because of reduced cosine losses as shown in Figure 3. The average annual energy for 19 different fixed flat-plate installations in California (Ref-4) ranged from $1,000 \mathrm{kWh}$ per rated $\mathrm{kW}$ to $1,500 \mathrm{kWh}$ per rated $\mathrm{kW}$. As will be shown later in this paper, the Amonix system generates in excess of 1,900 to 2,000 kWh per rated $\mathrm{kW}$ in the Phoenix, AZ area.

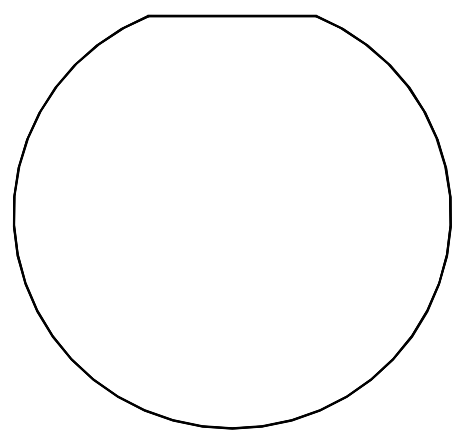

A single 6" wafer Produces 2 to 3 watts

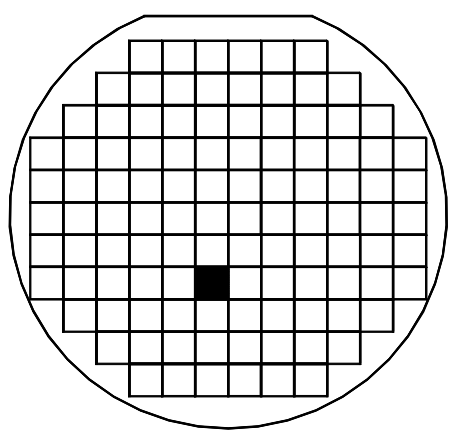

An Amonix 6” wafer

Produces over 1000

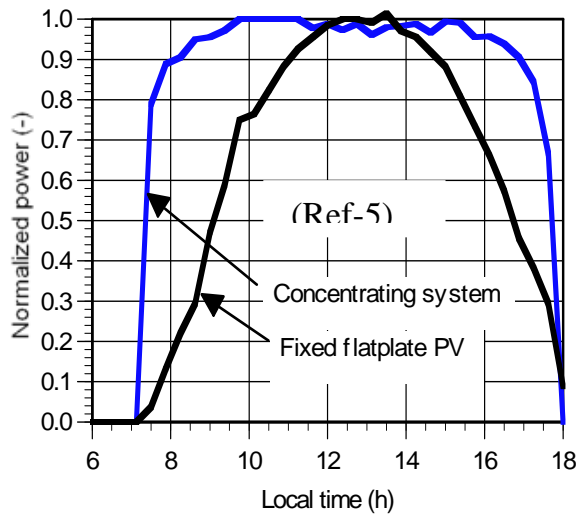

Figure 3. Daily power produced.

Figure 2. Concentrating reduces the material cost/watt.

\section{SYSTEM DESCRIPTION}

The Amonix system shown in Figure 1 consists of the following major subsystems noted in Figure 4:

- MegaModule subsystem - Concentrates the sun's energy on a solar cell that converts it into electrical energy. It consists of Fresnel lenses, solar cells, and structure. Each system consists of five to seven MegaModules.

- Drive subsystem - Rotates the MegaModules in azimuth and elevation to track the sun. The drive system consists of a foundation, pedestal, rotating bearing head, hydraulic actuators, and torque tube. 
- Hydraulic subsystem - Applies hydraulic pressure to one side of the hydraulic actuators to move the torque tube and MegaModules in elevation and azimuth in order to keep the system pointing at the sun. The hydraulic system consists of hydraulic valves, accumulator, pump, reservoir, and pressure sensors.

- Tracking control subsystem - Monitors sensors on the system, calculates the required movement for the commanded operation, and applies signals to the hydraulic valves to move the system to the commanded position. The commanded position could be to track the sun, move to a night stow position, move to a wind stow position, or move to a maintenance position.

- AC/DC control subsystem - Combines the DC power, converts it to AC power, and interfaces with the AC grid. It consists of DC fuses, circuit breakers, and inverter.

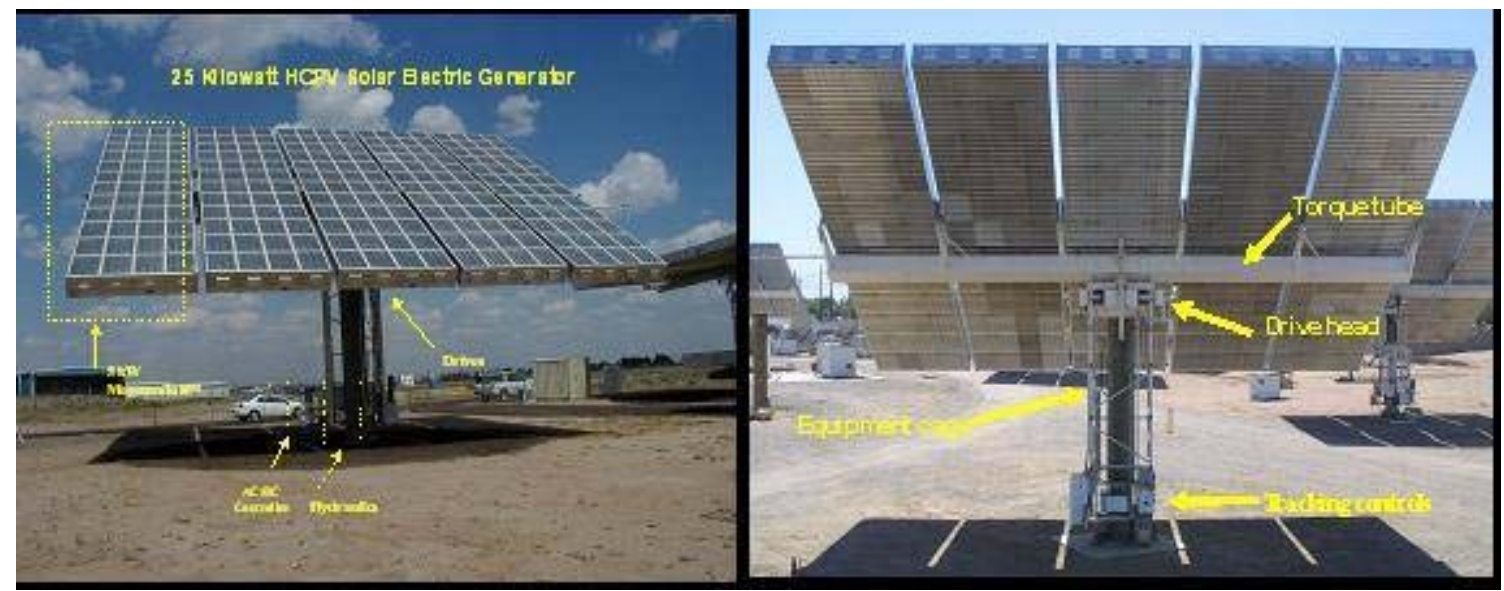

Figure 4. Major subsystems and components of the Amonix system.

Refractive optics is used to concentrate the sun's irradiance onto a solar cell, as illustrated in Figure 5. A square Fresnel lens, incorporating circular facets, is used to turn the sunrays to a central focal point. A solar cell is mounted at this focal point and converts the sun power into electrical power. A number of Fresnel lenses are manufactured as a single piece, or parquet. The solar cells are mounted on a plate, at locations corresponding to the focus of each Fresnel lens. A steel C-channel structure maintains the aligned positions of the lenses and cell plates. The lenses, cell plates, and steel structure are collectively referred to as an Amonix MegaModule $^{\mathrm{TM}}$ (see Figure 6). Each MegaModule ${ }^{\mathrm{TM}}$ is designed to produce $5 \mathrm{~kW}$ of DC power at $850 \mathrm{~W} / \mathrm{m}^{2}$

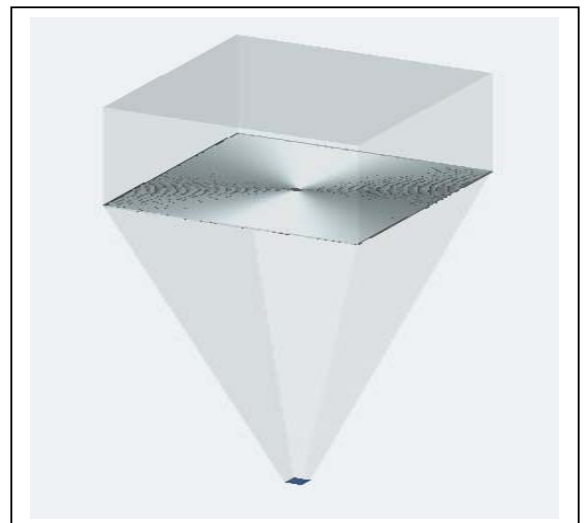

Figure 5. Fresnel lens concentrates the sun's power on the cell.

direct normal insolation and 20 deg $\mathrm{C}$ ambient temperature (IEEE standard). One to seven MegaModules $^{\mathrm{TM}}$ are mounted on a sun-tracking structure to obtain a $5 \mathrm{~kW}$ to $35 \mathrm{~kW}$ array, respectively (as shown in Figure 1). The physical characteristics of a $25 \mathrm{~kW}$ unit are shown in Table 1. 


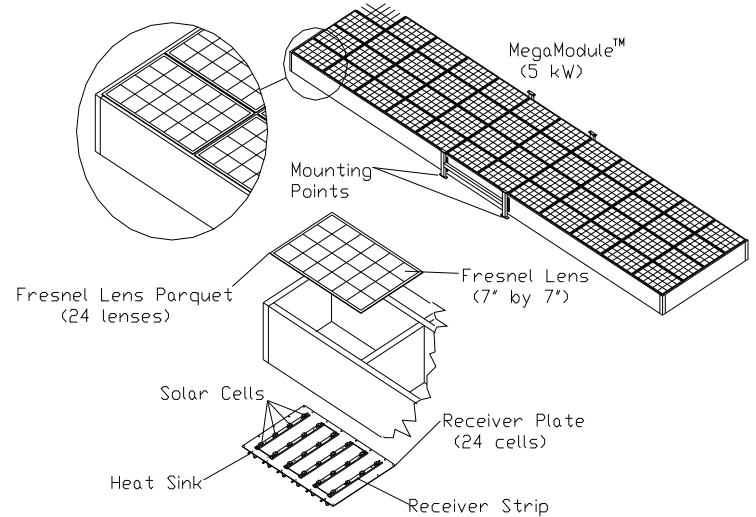

Figure 6. Amonix MegaModule ${ }^{\mathrm{TM}}$ major components.

\begin{tabular}{|l|l|}
\hline \multicolumn{2}{|l|}{ Table 1. Physical characteristics. } \\
\hline $\begin{array}{l}\text { Rated Power Output } \\
@ 850 \mathrm{~W} / \mathrm{m}^{2}, \\
25^{\circ} \mathrm{C}, 1 \mathrm{~m} / \mathrm{s} \text { wind }\end{array}$ & $25 \mathrm{~kW} \mathrm{AC}$ \\
\hline Number & $5 \mathrm{Modules}$ \\
\hline Collector Size (ft) & $55 \mathrm{x} 44 \times 2.5$ \\
\hline Aperture Lens Area & $1960 / 182\left(\mathrm{f}^{2} / \mathrm{m}^{2}\right)$ \\
\hline Total Face Area & $2508 / 233\left(\mathrm{f}^{2} / \mathrm{m}^{2}\right)$ \\
\hline Number Of Cells & 5,760 \\
\hline Concentration Ratio & $250: 1 \mathrm{suns}$ \\
\hline Operating Voltage & $277 / 480,3 \mathrm{ph} \mathrm{AC}$ \\
\hline Wind Stow Speed & $27 \mathrm{mph}$ \\
\hline Max. Wind Speed & $90 \mathrm{mph}$ \\
\hline
\end{tabular}

\section{SYSTEM OPERATION}

The system is designed for unattended operation for either grid- connected or off-grid applications. As has been described previously (Ref-6), the system moves automatically from a night stow position to tracking the sun in the early morning. It tracks the sun throughout the day, typically generating electrical power whenever the Direct Normal Irradiance (DNI) is above $400 \mathrm{~W} / \mathrm{m}^{2}$, until the sun sets in the evening. An example of the generated power profile is shown in Figure 7. The controller monitors the sun position with respect to the centerline of the unit and adjusts the tracking position if required to maintain the required pointing accuracy. If clouds occur during the

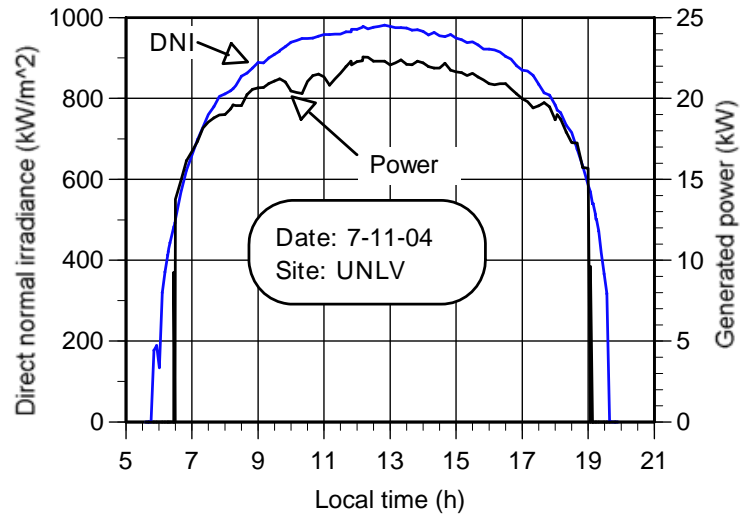

Figure 7. Example of a power profile over the day. day, sun-position mathematical algorithms are used to keep the unit pointing at the expected sun position until the clouds dissipate.

An unattended and/or remote system not only needs to be very reliable, but also needs to have good diagnostic information available that can be retrieved from a central or distant location. This system was designed with this in mind, and the diagnostic capability has been improved over the years of operation. The currents, voltages, and power data over the day are stored in memory. This data can then be used to determine if there is an inverter problem, fuse problem, PV string problem, tracking problem, or poor environmental conditions, etc. It can also be used to determine when the lenses have become soiled and need to be washed. Control system and hydraulic drive system data are also stored. The controller continuously checks a number of its operating parameters. If any of these parameters, such as fluid level, pump cycling frequency, etc., deviates from its normal operating range, it is noted, and the system can then be halted if necessary. This data is retrievable from a central operating facility and can be used to diagnose a current problem or to detect a potential future problem. Based on this data, it can then be decided not only when to send a maintenance person to the site, but also what equipment and parts that are needed for the repair. 


\section{DESCRIPTION OF PLANT SITES}

Over $570 \mathrm{~kW}$ of the $5^{\text {th }}$ generation Amonix system have been manufactured and installed over the last six years. The first three $20 \mathrm{~kW}$ units started operating in May of 2000 . Since that time, additional units have been manufactured and installed for Arizona Public Service (APS), and for the University of Nevada, Las Vegas. During this time, the units have produced over 3.5 GWh of grid power.

\section{APS STAR Center, West Field Site}

There are currently $145 \mathrm{~kW}$ in operation in the West field at the APS STAR facility in Tempe, Arizona. The field now consists of three $25 \mathrm{~kW}$ units and two $35 \mathrm{~kW}$ units. Initially there were three $20 \mathrm{~kW}$ units and three $25 \mathrm{~kW}$ units as shown in Figure $8 . \quad$ The MegaModules from the three $20 \mathrm{~kW}$ units were moved to a new $35 \mathrm{~kW}$ drive system. These units were installed during the period from 2000 to 2003 and represent different versions and

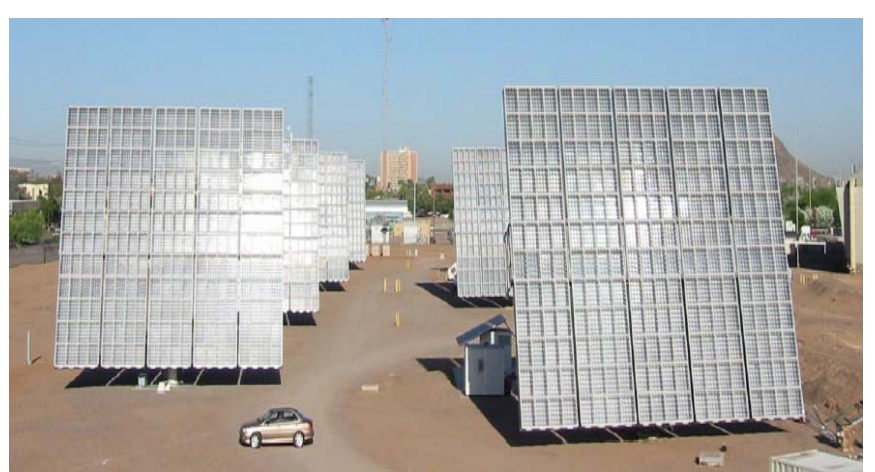

Figure 8. APS West field. configurations as the design matured. The $35 \mathrm{~kW}$ units, incorporating 7 MegaModules, are the latest design to be manufactured and installed at this site. The units in the west field have produced over 1,185 MWh of grid power since the start of operation.

\section{APS STAR Center, East Field Site}

A second field of Amonix units is located on the east side of the APS STAR facility (see Figure 9). There are five 25 $\mathrm{kW}$ units, for a total of $125 \mathrm{~kW}$, at this location. These units were installed during 2002 and have generated over 832 MWh of grid power.

\section{Glendale Arizona APS Site}

Units were installed in Glendale, Arizona (near Phoenix, AZ) during the first half of 2001. This site is located at the southwest corner of the Glendale airport. It consists of four $25 \mathrm{~kW}$ units, for a total of $100 \mathrm{~kW}$ as shown in Figure 10. Since installation, this site has produced over 626 MWh of grid power. There are no operating or maintenance personnel located at this site. The daily performance is remotely monitored from the APS STAR facility. When there is a

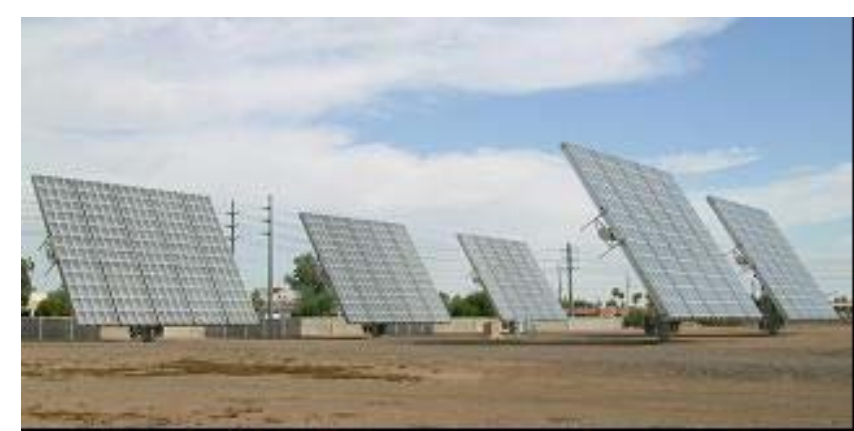

Figure 9. East field at the APS STAR facility.

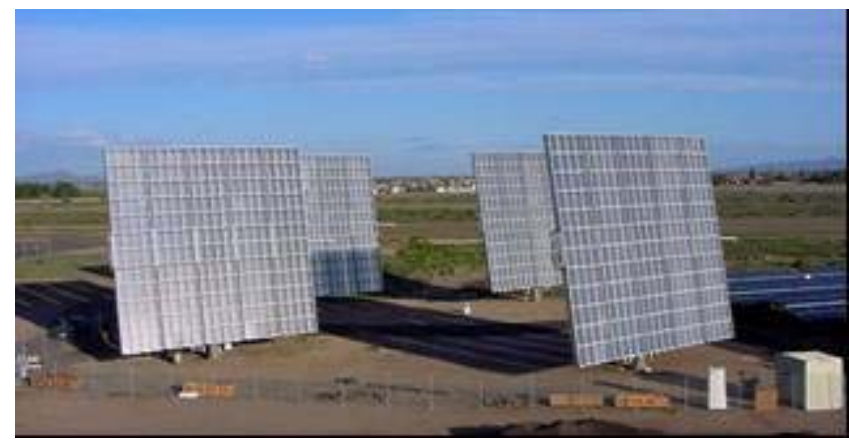

Figure 10. The APS Glendale airport site. 
problem, a maintenance person is sent out from the STAR facility.

\section{Prescott Arizona APS Site}

APS is currently constructing a concentrating PV plant near Prescott, Arizona. There are five $35 \mathrm{~kW}$ units in operation at this site. The first $35 \mathrm{~kW}$ unit began operating in late 2002. Four additional $35 \mathrm{~kW}$ units were installed in 2003, for a present total of $140 \mathrm{~kW}$. Figure 11 shows the five systems in operation. These five Amonix units have generated over $590 \mathrm{MWh}$ of grid power.

\section{University of Nevada in Las Vegas Site}

One Amonix $25 \mathrm{~kW}$ unit was installed at the Center for Energy Research at the University of Nevada in Las Vegas in March of 2004. This project is a joint effort by UNLV, Amonix, and Arizona Public Service under the direction of Mary Jane Hale of the National Renewable Energy Laboratory (NREL) and funded by the Nevada Southwest Energy Partnership.

This unit, shown in Figure 12, is being operated by the students to obtain energy and reliability performance data. Simultaneously, the students are learning about the technology. This system started operating in late March 2004 and has generated over $90 \mathrm{MWh}$ since that time.

\section{Nevada Power Company site in Las Vegas}

Amonix is currently manufacturing installing three $25 \mathrm{~kW}$ units for Nevada Company in Las Vegas. The site is located Nevada Power Clark Generating Station Southeast part of Las Vegas. Installat: foundations, pedestals, and drive systems al complete as shown in Figure 13. MegaModules are now being manufactured new receiver plate design. The installation operational in the March time frame.

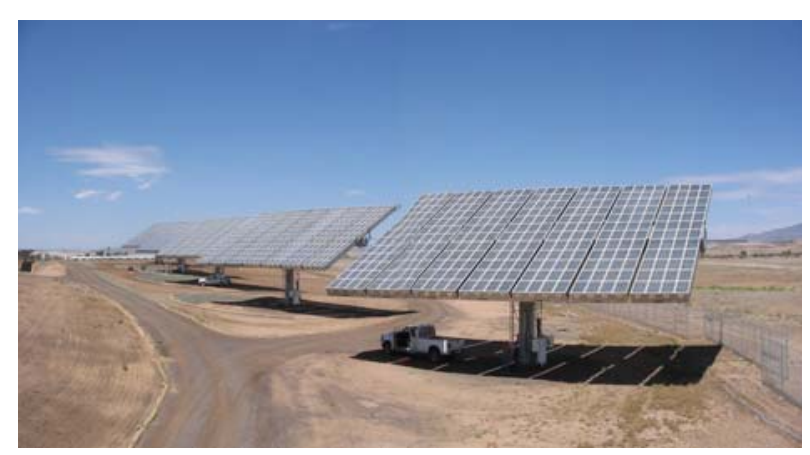

Figure 11. APS Prescott site.

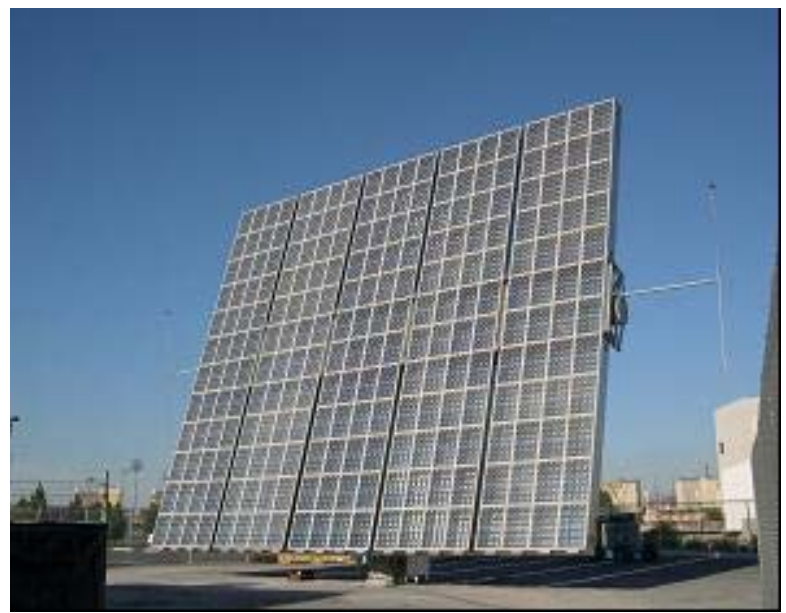

Figure 12. Unit operating at the UNLV site.

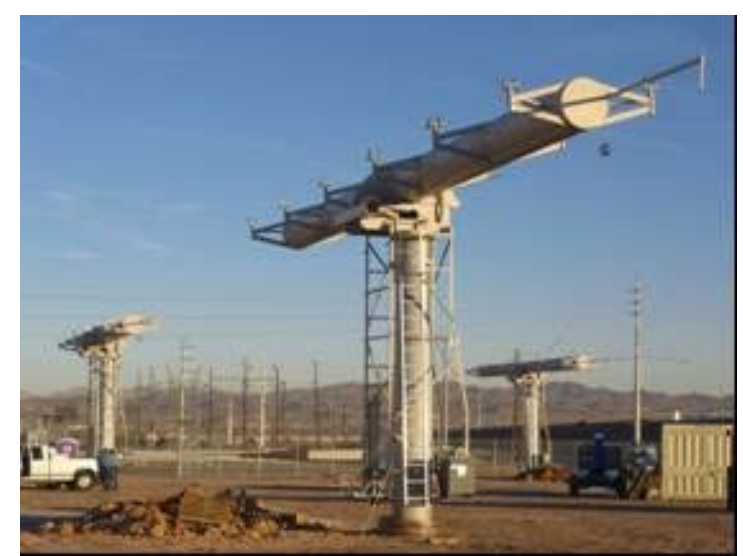

Figure 13. Nevada Power site. 


\section{SYSTEM PERFORMANCE}

Part of the Amonix development plan was to deploy one or more units at different possible solar sites in order to test the hardware under the various environment conditions to determine the operating performance. Units have been deployed in Southern California, Nevada, Arizona, Texas, and Georgia and there have been different lessons learned from the different sites. Some of the units have been in field operation for six years and the accumulated electrical grid energy as shown in Figure 14 is nearly $3.5 \mathrm{GWh}$.

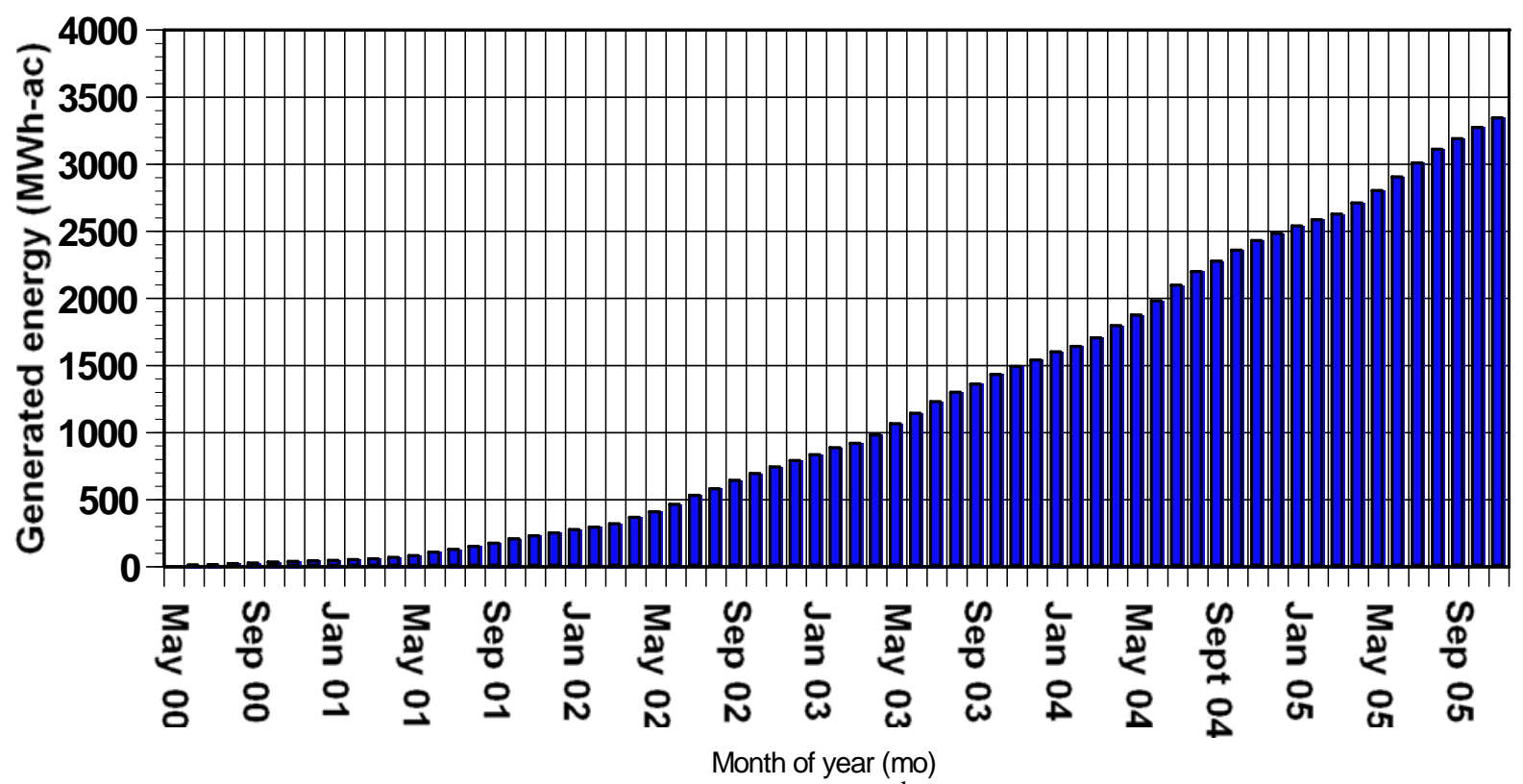

Figure 14. Accumulated grid energy generated by the $5^{\text {th }}$ generation.

There have been 117 MegaModules manufactured, not counting the ones being manufactured for Nevada Power, and installed in the field. These Modules consists of 5,616 receiver plates and 134,784 cells. The total field operating time is over 457 years as shown in Figure 15. As

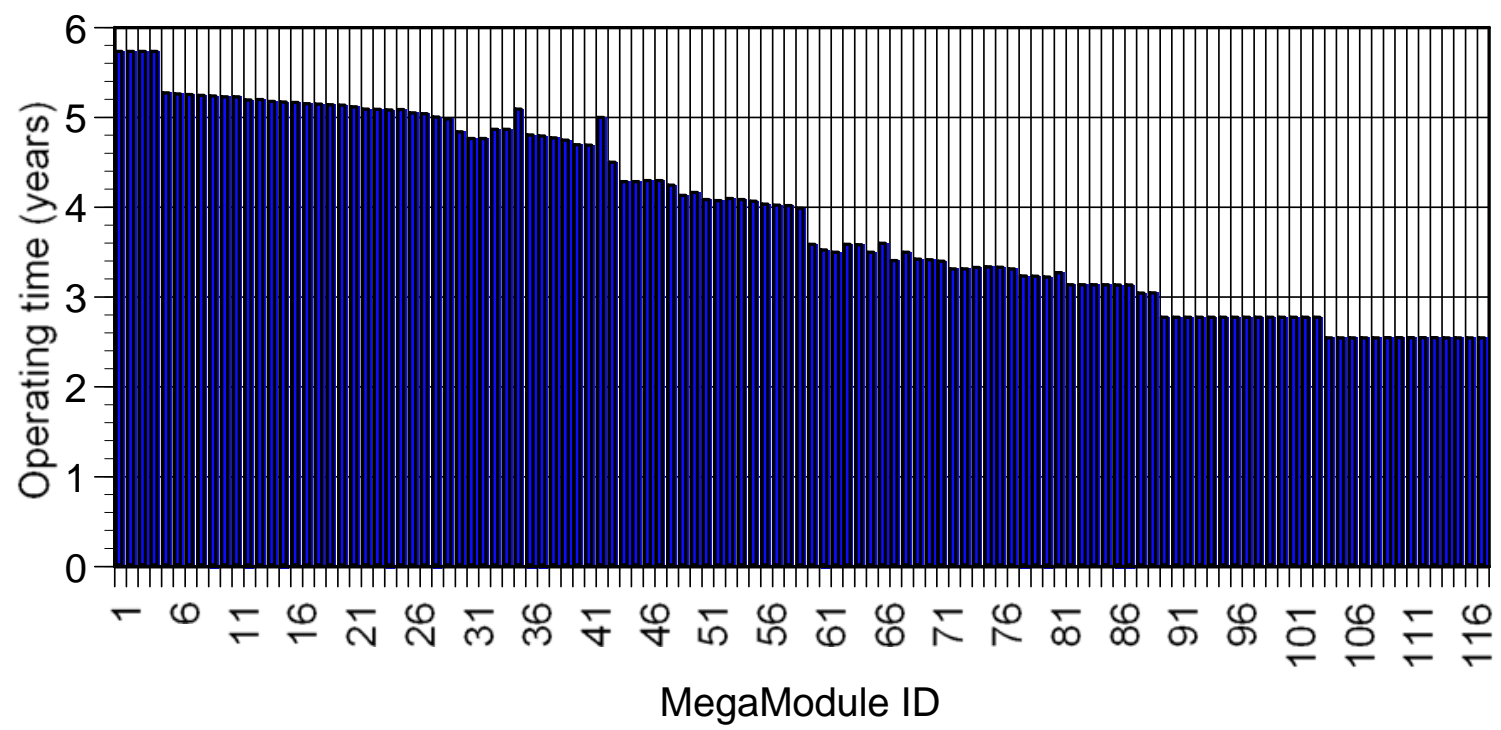

Figure 15. MegaModule field operating time. 
lessons were learned from both manufacturing and field-testing, design changes were made to increase performance, increase system reliability, and improve manufacturability of the system.

One of the main goals of the field-testing has been the assessment of long-term performance of the unit. The electrical power production of each field unit has been recorded from the time of installation. One of the first units installed was the W3 unit at the APS STAR facility. The total net monthly generated electrical energy for the W3 unit is shown in Figure 16. The performance was low in the first couple of months as issues were resolved with the new generation. The operation of this unit was discontinued in the later part of 2004 and the MegaModules were moved to a new drive system that was under development at the time. Because of the seasonal monthly and year-to-year variation in the incident sun irradiance and other factors such as soiling rate, temperature, wind, system outage time, etc., it is difficult to determine from this data whether the performance changed over this time period without further analysis.

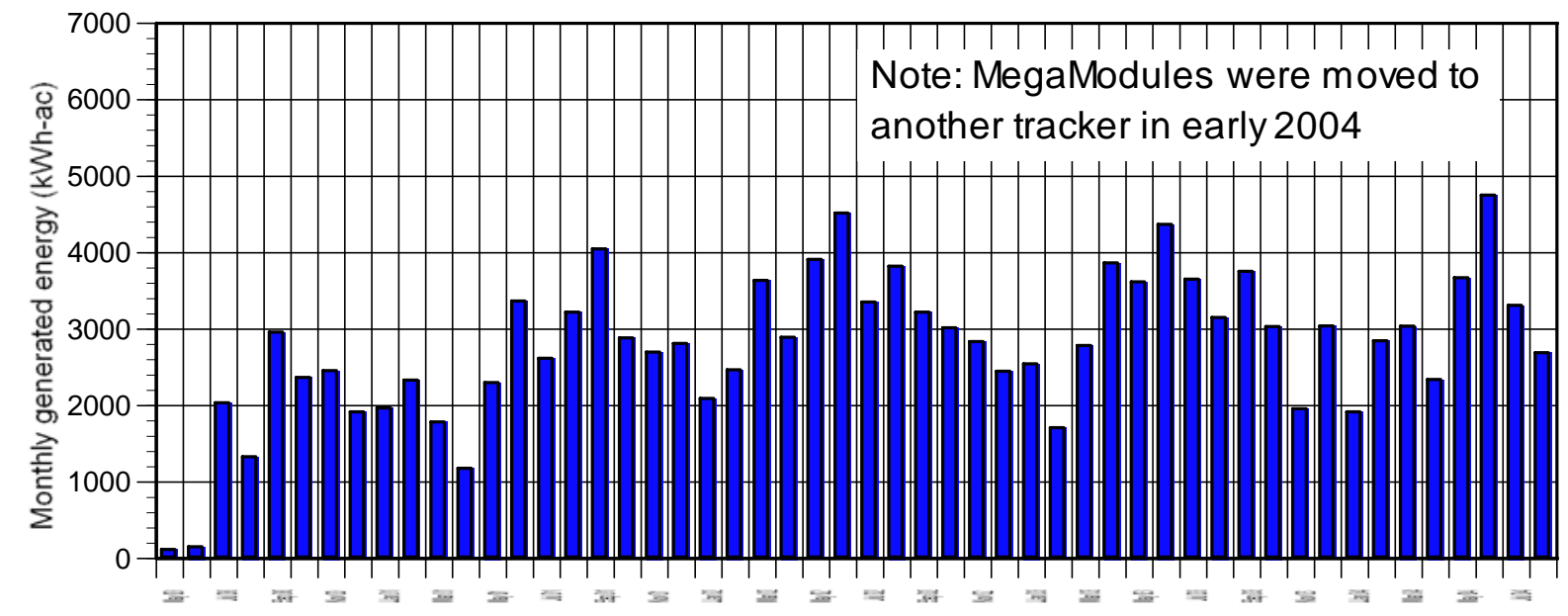

\section{Figure 16. Energy performance of the W3 unit at the APS STAR facility.}

A better estimate of the trend in the performance can be obtained by dividing the monthlygenerated energy by the integrated direct incident sun irradiance for the month. Since it is desirable to be able to compare the performance trend of one unit with other units of different size, this term is also divided by the rated power level. The resulting number is referred to as the monthly performance energy factor (MPEF). The MPEF for unit W3 is shown in Figure 17. The operation during the year 2000 is not shown because the direct normal irradiance for this time period was not available. The MegaModules on W3 are still in operation but the data analysis stops in mid 2004 because they were moved to a new drive system under development and are no longer together as a unit. Although the data presented in Figure 17 does not indicate any general degradation, there is still significant variation in the data points. As discussed above, this variation is the result of ambient temperature variation, wind speed variation, wind stow time, soiling rate, outage time, etc. The low point for May of 2001 (month 5) and April 2004 (month 4) were the result of problem outage for an extended period of time during the month. 


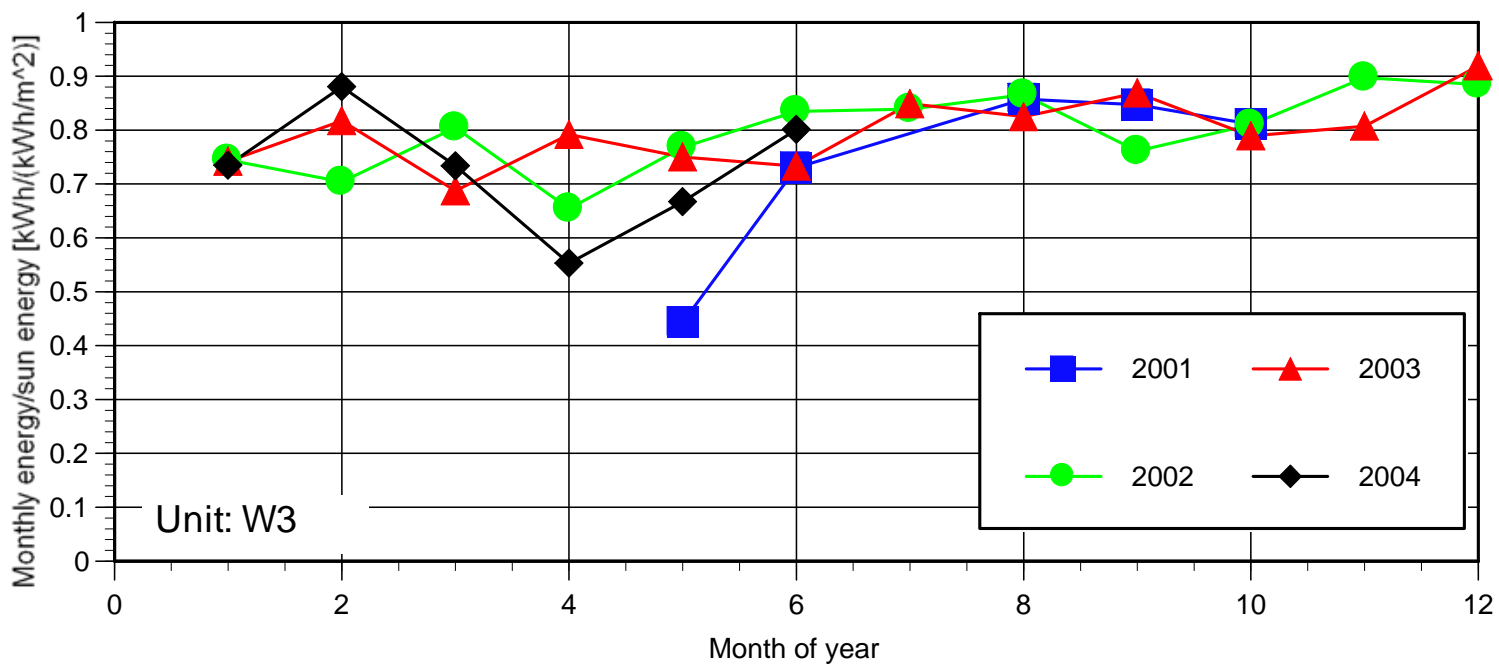

Figure 17. Monthly energy performance of unit W3.

An additional parameter that is calculated at the UNLV site is the integrated sun energy only when the system is generating power. Since one of the primary areas of interest is in the performance of the power conversion system, i.e., the MegaModule and inverter, the integrated sun energy when the system is generating power would remove the variation resulting from wind stow time and outage time. This is expected to reduce the variations in the MEPF that will result in a better estimate of the energy performance of the power conversion system. The MEPF for the UNLV program is shown in Figure 18. The calculation of the integrated sun energy when the system is generating power did not start until the beginning of 2005 and was not performed for most of the 2004 data.

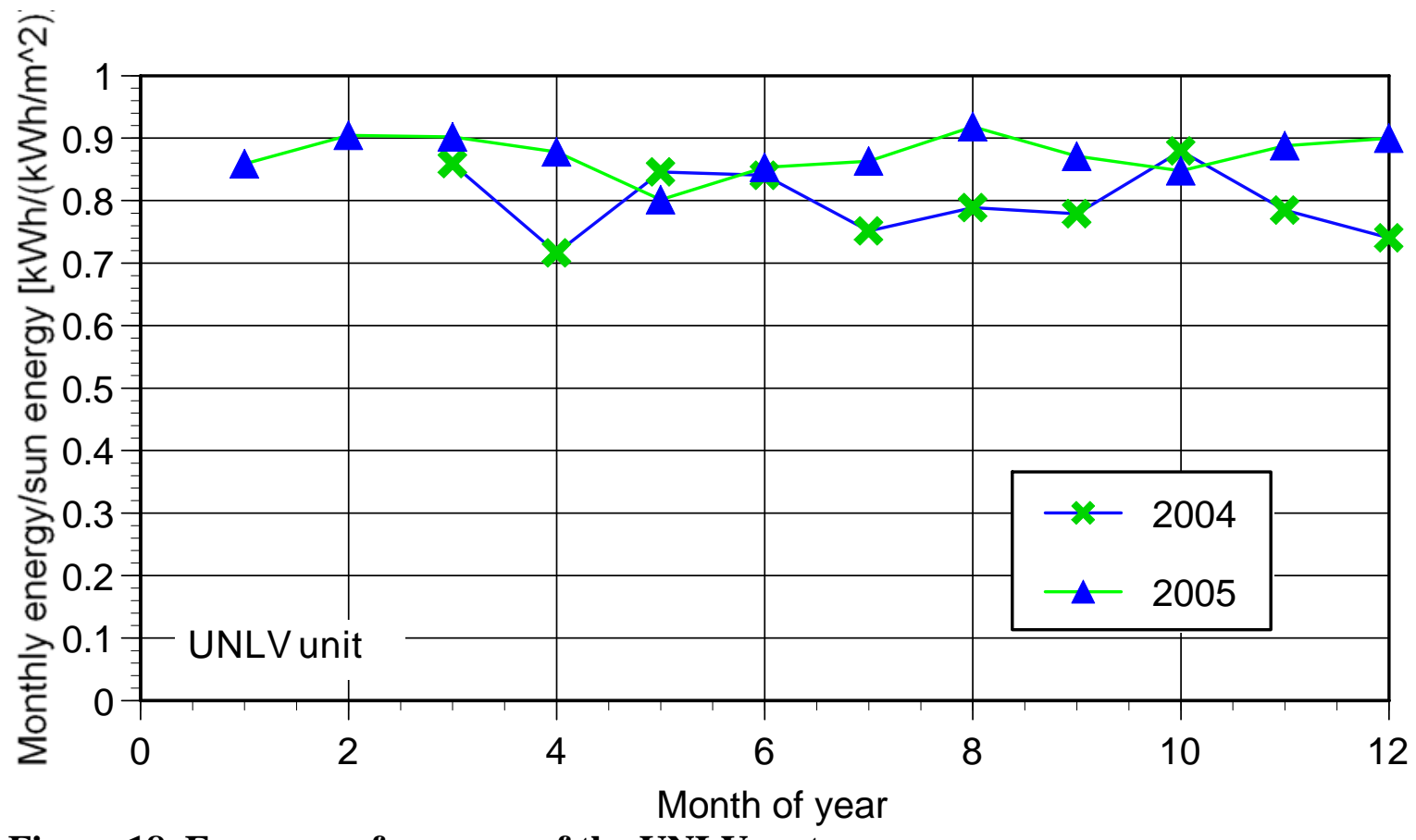

Figure 18. Energy performance of the UNLV system. 
Some of the data points in Figure 17 are higher than the previous year's, which would indicate that the energy performance is not decreasing. For the UNLV data in Figure 18, the energy performance factor for most months in 2005 is higher than the corresponding ones in 2004. Additional data are needed in order to determine any trend.

The peak power of the units is another performance parameter that is being monitored. The peak power normalized by the direct normal irradiance (DNI) for the W3 unit is shown in Figure 19. Power data before 2003 was not available and the MegaModules were move in the mid part of 2004. This performance is presently being calculated for other units in the field.

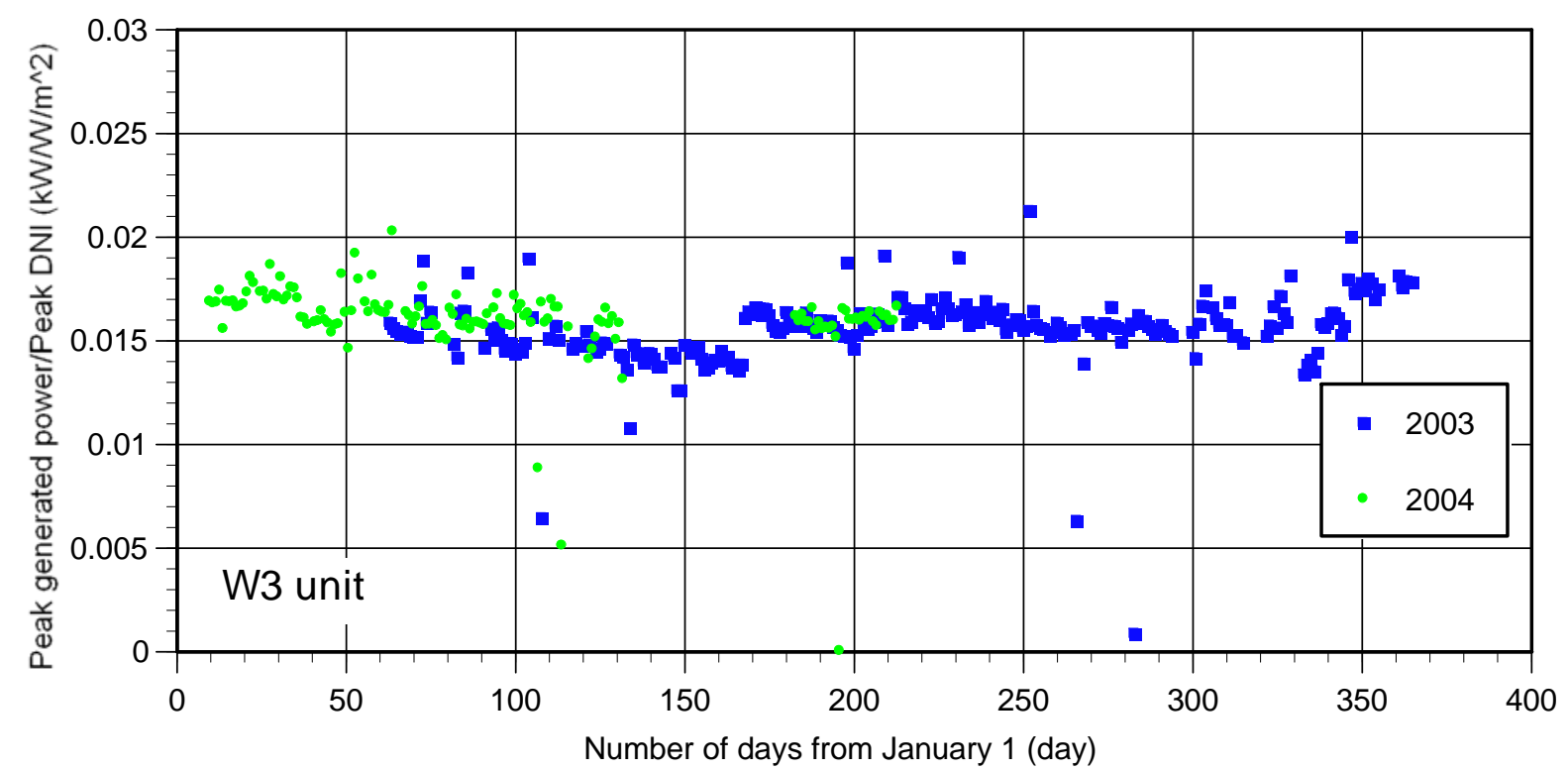

Figure 19. Daily peak power normalized by the DNI

\section{RELIABILITY PERFORMANCE \& O\&M REQUIREMENTS}

One of the main focuses of the UNLV program is to accumulate a reliability and O\&M database. As described in Reference 7, the database has been divided into two categories. The first is referred to as an incident and the second as a failure. The distinction between the two terms is that with an incident there is no material cost only a labor cost and there is both a labor, material, and perhaps a repair cost associated with a failure. In general an incident is something very minor such as a person making an adjustment to a sensor, rebooting the system, reinserting a connector or board, etc. In contrast, a failure will require the replacement of a component that requires both labor and material cost. The replaced component will have to be repaired unless it is a throw away component.

In order to identify the areas that need design attention, the system was broken into an incident/failure tree composed of the subsystems and main components. The incident/failure tree is shown in Table 2. Also shown in Table 2 are the number of incidents, number of failures, the mean time between incidents (MTBI) and the mean time between failures (MTBF). The time base used in these calculations is on-sun generating time and not elapsed time or operating time. This is very conservative since the drive bearing, actuators, hydraulics, control components operate the entire day whether the system is generating power or not. The time base for the electronic hardware should be based upon a 24 hour a day since power is left on all the time. 
Therefore the MTBI/F for these components should be much longer than the values shown in Table 2. The time base for the MegaModules

\begin{tabular}{|c|c|c|c|c|c|c|}
\hline \multicolumn{3}{|c|}{ Table 2. Unit incident and failure tree. } & \multirow{2}{*}{\multicolumn{2}{|c|}{ Number of }} & \multirow{2}{*}{\multicolumn{2}{|c|}{ Mean time between }} \\
\hline & & & & & & \\
\hline & & & Incident & Failure & Incident & Failure \\
\hline & 2.0 MegaModule & $2.1 \mathrm{Misc}$ & 0 & 0 & 5857 & 5857 \\
\hline & & 2.2 Receiver plates & 0 & 0 & 5857 & 5857 \\
\hline & & 2.3 Fresnel lens & 0 & 0 & 5857 & 5857 \\
\hline & & 2.4 Connectors & 0 & 0 & 5857 & 5857 \\
\hline & \multicolumn{2}{|r|}{ Total for subsystem $2.0=$} & 0 & 0 & 5857 & 5857 \\
\hline & & & & & & \\
\hline & 3.0 AC/DC interface & 3.1 Misc & 0 & 0 & 5257 & 5257 \\
\hline & & $3.2 \mathrm{AC}$ controls & 3 & 1 & 1314 & 5257 \\
\hline & & 3.3 Inverter & 19 & 4 & 263 & 1314 \\
\hline & & 3.4 DC controls & 0 & 0 & 2176 & 5257 \\
\hline & \multicolumn{2}{|c|}{ Total for subsystem $3.0=$} & 22 & 5 & 236 & 1752 \\
\hline & & & & & & \\
\hline & 4.0 Drive & 4.1 Misc & 0 & 0 & 5257 & 5257 \\
\hline & & 4.2 Azimuth ram & 0 & 0 & 5257 & 5257 \\
\hline & & 4.3 Elevation ram & 0 & 0 & 5257 & 5257 \\
\hline & & tal for subsystem $4.0=$ & 0 & 0 & 5257 & 5257 \\
\hline & & & & & & \\
\hline \multirow[t]{14}{*}{1.0 System } & 5.0 Hydraulics & 5.1 Misc & 0 & 0 & 5257 & 5257 \\
\hline & & 5.2 Valves & 0 & 2 & 5257 & 1752 \\
\hline & & 5.3 Sensors & 0 & 0 & 5257 & 5257 \\
\hline & & 5.4 Pump/controls & 0 & 0 & 5257 & 5257 \\
\hline & & 5.5 Hydraulic lines & 0 & 0 & 5257 & 5257 \\
\hline & \multicolumn{2}{|r|}{ Total for subsystem $5.0=$} & 0 & 2 & 5257 & 1752 \\
\hline & & & & & & \\
\hline & 6.0 Electronic controls & 6.1 Misc & 0 & 0 & 5257 & 5257 \\
\hline & & 6.2 Sun sensor & 1 & 0 & 2629 & 5257 \\
\hline & & 6.3 Encoders & 6 & 1 & 751 & 2629 \\
\hline & & \begin{tabular}{|l|}
6.4 Wind sensors \\
\end{tabular} & 0 & 0 & 5257 & 5257 \\
\hline & & 6.5 Control electronics/\$ & 18 & 1 & 277 & 2629 \\
\hline & & 6.6 Tracking & 4 & 0 & 1051 & 5257 \\
\hline & & tal for subsystem $6.0=$ & 29 & 2 & 175 & 1752 \\
\hline
\end{tabular}

is longer than the other components because they operated at the APS site while the UNLV site was being designed and constructed.

The time it takes to service the unit has also been recorded. The O\&M time does not include the time for washing the lenses nor does it include travel time. If the O\&M personnel were not on site or if personnel from Amonix or APS had to travel to the site, their travel time is not included, only their on-site time. If the on-site O\&M personnel had to call for assistance, only the time of the on-site personnel is included. A plot of the accumulated incident and failure labor time is shown in Figure 20 and the total incident and failure labor time per day is shown in Figure 21. 


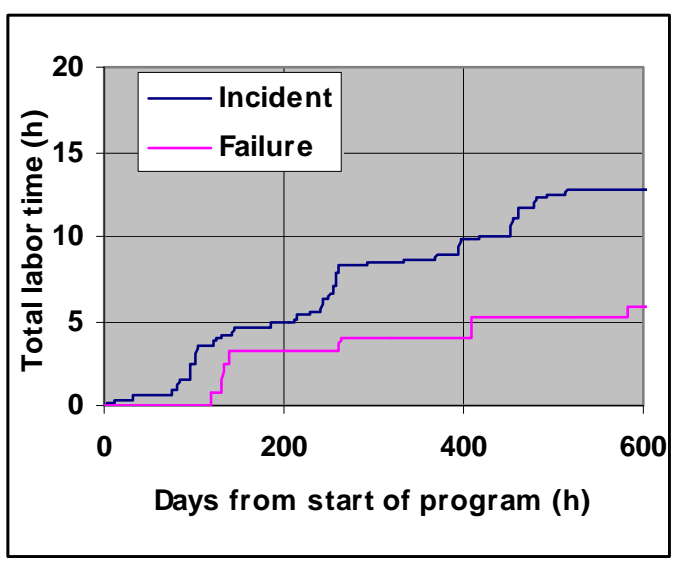

Figure 20. Incident \& failure time.

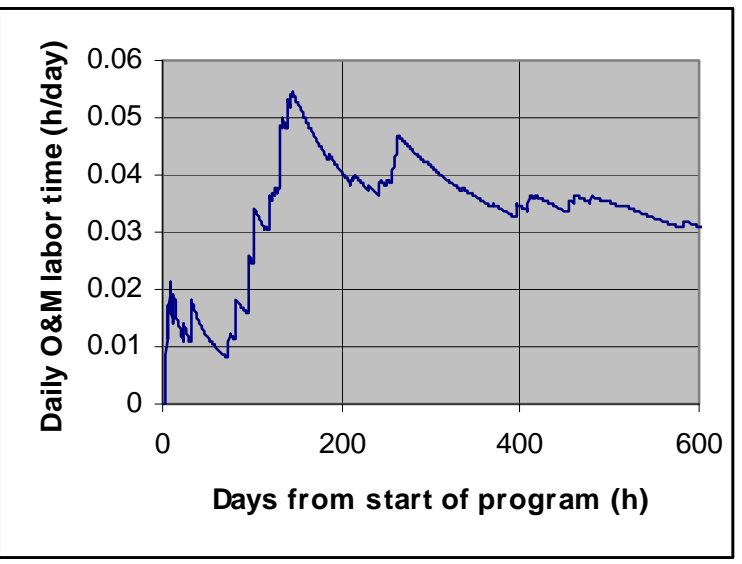

Figure 21. O\&M time per day.

\section{Summary}

Recognizing that a new technology like the high concentration photovoltaic system must be very reliable, easily manufacturable, and must be capable of meeting the market price before it could succeed in the commercial market place. Amonix developed such a plan in the 1990's to commercialize this technology. In following this development plan, Amonix has designed, fabricated, and field-tested several design generations. With over $500 \mathrm{~kW}$ of systems in operation, Amonix has taken the lessons learned from the manufacturing process and field testing and incorporated them into the next generation. With mounting orders, Amonix over the last year has been designing and fabricating the equipment required for producing $10 \mathrm{MW}$ of cells per year and has started fabricating a sixth generation prototype MegaModule.

\section{References}

1 - SunLab - NREL/Sandia, http://www.energylan.sandia.gov/sunlab/overview.htm

2 - Stolte, W. J., "Engineering and Economic Evaluation of Central-Station Photovoltaic Power Plants,” Electrical Power Research Institute, TR-101255, Research Projects 3166-01: 327303, December 1992

3 -McDonnell, F. L,, “High Power Density Photovoltaics,” Renewable Energy World, September-October 2002

4 - Scheuermann, K., Boleyn, D. R., Lilly, P. N., Miller, S., 2002, “Measured Output for

Nineteen Residential PV Systems: Updated Analysis of Actual System Performance and Net Metering Impacts,” Solar 2002, National Solar Energy Conference, ASME International, Reno, Nevada, June 15-20..

5 - Hayden, H., Johnston, P., “APS Installation And Operation Of 300 kW Of Amonix High Concentration PV Systems," Proceedings of the $29^{\text {th }}$ IEEE Photovoltaic Specialists Conference 2002, IEE Catalog \#02CH37361C.

6 - Stone, K. W.; Garboushian, V.; Dutra, D., Hayden, H.; “Operation of 350 kW of Amonix’s High Concentration PV System At Arizona Public Service Utility,” International Solar Energy Conference, Mauna Kea Resort, Kohala Coast Hawaii, ISEC2003-44081, March 1518, 2003. 


\title{
27.6\% Efficient Silicon Concentrator Solar Cells for Mass Production
}

\author{
Alexander Slade and Vahan Garboushian \\ Amonix Inc. \\ 3425 Fujita Street Torrance CA 90505 USA \\ email: alex@amonix.com
}

\begin{abstract}
Amonix began silicon concentrator cell development in the late 1980s. This work was done in semiconductor manufacturing facilities due to the low volumes required in the development phase. The issues involved in integrating a solar cell processing sequence in a microelectronics foundry will be discussed, including minority carrier lifetime and diffusion uniformity. Recently, Amonix has undertaken the commercialization phase of the solar cell development which bore processing simplifications, yield improvement, cost reduction and performance improvement. The solar cells produced with this new low-cost process have been measured by independent labs to be over $27 \%$ at $100 x, 26 \%$ at $250 \mathrm{x}$ and $25 \%$ at $400 \mathrm{x}$.
\end{abstract}

Key Words: Crystalline silicon solar cells, concentrator cells, high-efficiency.

\section{Introduction}

High concentration photovoltaic systems have been under development since the 1970s. Part of this initial work was done by Schwartz at Purdue University. Schwartz proposed a rear junction, back-contact device [1] that was subsequently developed by Swanson et alia at Stanford University [2]. During this time Amonix was also undertaking concentrator cell development and has maintained the development. This development was performed in conjunction with semiconductor manufacturing facilities for two reasons. The first reason was to lower the development cost by using equipment owed by another company and process wafers during the slow periods of that company. The second reason was that concentrator cells operate at very high current densities so precise manufacturing is required to maintain a very low series resistance (below $3 \mathrm{~m} \Omega \cdot \mathrm{cm}^{2}$ ).

Amonix is now producing these cells in a production environment and plans to ramp up production to achieve a throughput of $10 \mathrm{MW}$ by the end of 2005 .

\section{Development of production grade concentrator solar cells}

The essential aspect to the solar cell development has been production worthiness - wafer yield, electronic yield, process simplicity, process control, consistency and most all cost. To be able to meet the cost target of $\$ 0.20$ / Watt for the solar cell a very low cost (relative to other semiconductor products) process must be used.

The uniqueness of the challenge is unparallel in PV today where every technology uses either custom made equipment often costing millions of dollars or equipment dedicated to the manufacture and / or deposition of a thin film technology. Amonix uses only existing (primarily used) equipment from the semiconductor industry. This has the obvious advantage that the costs can be quite low and the technology is constantly improving without any cost to Amonix. An example of this is that the entire amount of money spent on new equipment for the $10 \mathrm{MW}$ facility is approximately $\$ 50,000$ although a lot more was spent on used equipment. One particular piece of new equipment was the Ron Sinton lifetime tester. This has been a very valuable tool as the semiconductor foundries have little or no use for measuring minority carrier lifetime. However, after having used this tool for the last 3 years (during development) the semiconductor manufacturing facility now measures the lifetime of float zone wafers for all 40 diffusion furnaces to monitor contamination. Results of the lifetime / contamination have been reported previously [3]. The only other piece of equipment that was purchased new was the silicon etching equipment as Amonix is the only customer of the semiconductor foundry that etches silicon (surface texturing).

\section{Measurements of silicon concentrator cell performance}

The other important aspect of development is device performance. However, it has been a difficult task to get reliable independent measurement of cell efficiency as the high lifetime back-contact solar cell is very difficult to use on a flash testing system. Also, as multi-junction concentrator cells are the flavor of the month, most concentrator cell testing efforts have been in that direction. Therefore, the testing of silicon concentrator cells had to be somewhat re-developed to accommodate only Amonix as we are the only company currently working on high concentration silicon solar cells.

There have been two aspects of testing these cells that have proven difficult, 1) calibration of input illumination power, and 2) accurate curve tracing under flash illumination.

The first of these problems has been addressed in two ways. Gerald Siefer at the Fraunhofer Institute used three independent lamps of high intensity. The method consists of illuminating the cell with each lamp, then with two of the three lamps, then with all three lamps and measuring the short circuit current $\left(\mathrm{I}_{\mathrm{sc}}\right)$ of the cell under each condition. By comparing the expected $\mathrm{I}_{\mathrm{sc}}$ with the measured $\mathrm{I}_{\mathrm{sc}}$ of each condition, the linearity is obtained, see table I. 


\begin{tabular}{|c|c|c|c|c|c|c|}
\hline$\# 1$ & $\# 2$ & $\# 3$ & $\begin{array}{l}I_{\text {sc }} \\
(\mathrm{mA})\end{array}$ & $\begin{array}{l}\text { Conc. } \\
(\text { Suns })\end{array}$ & $\begin{array}{l}\text { Exp. } I_{\text {sc }} \\
(\mathrm{mA})\end{array}$ & Linearity \\
\hline $\mathbf{X}$ & & & 1354 & 32.5 & & \\
\hline & $\mathbf{X}$ & & 1340 & 32.1 & & \\
\hline & & $\mathbf{X}$ & 817 & 19.6 & & \\
\hline $\mathbf{X}$ & $\mathbf{X}$ & & 2672 & 64.1 & 2694 & $99 \%$ \\
\hline $\mathbf{X}$ & & $\mathbf{X}$ & 2167 & 52.0 & 2171 & $100 \%$ \\
\hline & $\mathbf{X}$ & $\mathbf{X}$ & 2146 & 51.5 & 2157 & $99 \%$ \\
\hline $\mathbf{X}$ & $\mathbf{X}$ & $\mathbf{X}$ & 3470 & 83.2 & 3511 & $99 \%$ \\
\hline
\end{tabular}

Table I Presented above are measurements of $I_{s c}$ as a function of independent multiple light sources to assess linearity.

The Fraunhofer measurements clearly show that the cells are linear $(+/-0.5 \%)$ up to $83 \mathrm{x}$. The limitation of this method is the stability of the light sources. This limits the intensity that this method can used to measure. However, it does show linearity to a medium level of concentration.

Another method of calibrating the measurement of the concentrator cells measurements is to have a small solar cell very close to the cell being measured. This method provides a direct measurement of the illumination level. The drawback is that the small cell used in the testing stage must be accurately calibrated. James Kiehl at NREL has used a GaInP solar cell to measure the light intensity of the flash during silicon concentrator cell measurements. This is considered a reliable means of calibration because the GaInP solar cells have a linear response to illumination due to their direct band gap. Recent results of linearity measured at NREL are shown in figure 1 .

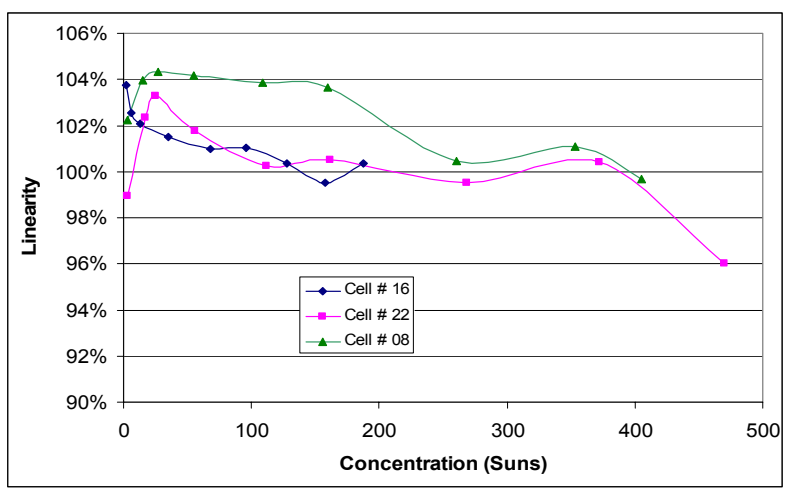

Figure 1 Presented above are measurements of the $I_{s c}$ linearity relative to a GaInP solar cell.

These results from NREL show that the cells are linear up to $400 x$, relative to a GaInP solar cell. NREL also performed curve traces of these cells under flash light illumination, see table II.

\begin{tabular}{|r|r|r|r|r|}
\hline C [suns] & Eff. [\%] & FF [\%] & $V_{\text {oc }}[\mathrm{mV}]$ & \multicolumn{1}{l|}{$\mathrm{I}_{\mathrm{sc}}[\mathrm{A}]$} \\
\hline 260 & 26.3 & 78.8 & 830 & 10.5 \\
\hline 353 & 25.9 & 76.6 & 836 & 14.3 \\
\hline 405 & 25.3 & 75.7 & 838 & 16.1 \\
\hline
\end{tabular}

Table II Presented above are measurements of the efficiency of Amonix's simplified rear junction, back contact concentrator solar cell measured at NREL.
Due to biasing issues at NREL only IV curves under high illumination are measured accurately. This is due to the reduction in minority carrier lifetime under very high injection conditions due to increased Auger recombination. The lower lifetime reduces the junction capacitance negating the biasing problems. The high efficiency at $405 \mathrm{x}$ is very encouraging that silicon back contact cells can be made to operate under much higher concentrations than has been used in the past. The cells measured by NREL were $125 \mu \mathrm{m}$ thick with thin metallization. As production proceeds it is envisaged that the metallization will be improved. This change will increase the efficiency at the current operating point and for concentrations over 500x.

For completeness, results are presented in table III of the efficiency for the simplified high concentration silicon solar cell made by Amonix Inc. The measurements were made at the Fraunhofer Institute.

\begin{tabular}{|c|c|c|c|c|}
\hline $\begin{array}{c}\mathrm{C} \\
\text { [suns] }\end{array}$ & $\begin{array}{c}\text { Efficiency } \\
{[\%]}\end{array}$ & $\mathrm{FF}[\%]$ & $\begin{array}{c}\mathrm{V}_{\text {oc }} \\
{[\mathrm{mV}]}\end{array}$ & $\mathrm{I}_{\mathrm{sc}}[\mathrm{mA}]$ \\
\hline 7.7 & 25.0 & 81.2 & 737 & 320 \\
\hline 17.4 & 26.2 & 82.4 & 761 & 727 \\
\hline 34.0 & 26.8 & 82.2 & 780 & 1417 \\
\hline 65.4 & 27.2 & 81.9 & 797 & 2729 \\
\hline 92.3 & 27.6 & 82.0 & 808 & 3847 \\
\hline 122.4 & 27.5 & 81.0 & 815 & 5102 \\
\hline
\end{tabular}

Table III Efficiency of Amonix's simplified rear junction, back contact concentrator solar cell measured at Fraunhofer Institute. The efficiency shown in table was calculated based on $100 \%$ linearity.

\section{Conclusion}

The peak efficiency of the Amonix solar cells is at a concentration of $\sim 100 x$. Predominately, the efficiency at higher concentration is dependent on the series resistance, which is soon to be addressed.

The important aspects of all of the measurements presented here is that the design of the solar cell and the thickness of 125 $\mu \mathrm{m}$ is sufficient for linear behavior of the $\mathrm{I}_{\mathrm{sc}}$ up to $400 \mathrm{x}$.

Therefore, further improvement of the Amonix solar cells' efficiency now relies on advancing the production metallization process.

\section{Acknowledgements and References}

The authors wish to thank the time and effort that both James Kiehl and Gerald Siefer gave to this project.

[1] M. D. Lammert and R. J. Schwartz, IEEE Trans. Elec. Dev. ED-24 (4) (1977) pp. 337-342.

[2] R. M. Swanson, $17^{\text {th }}$ IEEE PVSC (1984) pp. 1294-1296.

[3] A. M. Slade, R. Gordon and V. Garboushian, EU PVSEC (2004) pp. 600-603 